\title{
OVERVIEW OF THE STATE OF KNOWLEDGE ON PALEOTECTONIC STRESSES AND THEIR IMPLICATIONS FOR SOLUTION OF GEOLOGICAL PROBLEMS
}

\author{
L. A. Sim \\ The Schmidt Institute of Physics of the Earth RAS, Moscow, Russia
}

\begin{abstract}
The most informative geological indicators of tectonic stress are faults on all scales and minor structural forms, such as dikes, mineralized veins, shear fractures, cleavage, slikenlines on slip planes of any genesis, foliation, cleavage, stilolite joints, hinges and axial planes of folds and flexures, etc. These indicators are analysed by various field tectonophysical methods developed in different countries. The article gives an overview of the history of the most widely used methods of tectonophysical paleotectonic stress reconstructions for geological structures of various scales. Reviewed are results of regional tectonophysical studies aimed at mapping paleotectonic stress and solution of possible mechanisms of formation of the structures located mainly in the territory of Russia and CIS countries. Special attention is given to application of results of the tectonic stress studies for solution of practical problems.
\end{abstract}

Key words: tectonic stresses, fracturing, slikenlines, phases and cycles of deformation, Lode-Nadai coefficient, vertical decompression of rocks.

Recommended by Yu.L. Rebetsky

Citation: Sim L.A. 2013. Overview of the state of knowledge on paleotectonic stresses and their implications for solution of geological problems. Geodynamics \& Tectonophysics 4 (3), 341-361. doi:10.5800/GT-2013-4-30105.

\section{КРАТКИЙ ОБЗОР СОСТОЯНИЯ ИЗУЧЕННОСТИ ПАЛЕОТЕКТОНИЧЕСКИХ НАПРЯЖЕНИЙ И ИХ ЗНАЧЕНИЕ ДЛЯ РЕШЕНИЯ ГЕОЛОГИЧЕСКИХ ЗАДАЧ}

\author{
Л. А. Сим \\ Институт физики Земли им. О.Ю. Шмидта РАН, Москва, Россия
}

Аннотация: Наиболее информативными геологическими индикаторами тектонических напряжений являются разрывные нарушения разного масштаба, мелкие структурные формы: дайки, минерализованные жилы, трещины скола и отрыва, борозды скольжения на плоскостях любого генезиса, сланцеватость, кливаж, стилолитовые швы, шарниры и осевые плоскости складок и флексур и т.д. Эти индикаторы анализируются различными полевыми тектонофизическими методами, разработанными в разных странах. В статье кратко рассмотрена история развития наиболее широко используемых тектонофизических методов реконструкций палеотектонических напряжений в разномасштабных геологических структурах, перечислены результаты региональных тектонофизических исследований. Эти исследования были направлены на картирование палеотектонических напряжений и решение вопросов о возможных меха- 
L.A. Sim: Overview of the state of knowledge on paleotectonic stresses...

низмах формирования структур преимущественно на территории России и стран СНГ. Особое внимание уделено использованию результатов изучения тектонических напряжений в решении практических задач.

Ключевые слова: тектонические напряжения, трещиноватость, борозды скольжения, фазы и циклы деформирования, коэффициент Лоде-Надаи, вертикальное разуплотнение горных пород.

\section{1. ВВЕДЕНИЕ}

В 2014 г. исполнится 60 лет с начала реконструкции палеотектонических напряжений по геологическим индикаторам. Инициатива этих работ принадлежит одному из основателей отечественной тектонофизики - М.В. Гзовскому. За это время полевая тектонофизика ушла далеко вперед в изучении тектонических напряжений в самых различных по генезису и по возрасту тектонических структурах, в сопоставлении палеонапряжений с современными, изучаемыми по сейсмологическим данным и инструментальным измерениям напряжений in situ и т.д. Специфика геологических объектов обусловила как неоднократную модификацию существующих методов изучения тектонических напряжений, так и разработку новых, направленных на уточнение возраста палеонапряжений, расширение спектра получаемых параметров напряженного состояния, понимание и расшифровку механизмов формирования структур.

За прошедшие десятилетия проведено картирование палеотектонических напряжений значительной части территории бывшего Советского Союза. Благодаря этим работам, а также углубленному крупномасштабному изучению напряженного состояния отдельных структур (особенно тектонических напряжений отдельных рудных, нерудных и углеводородных месторождений, объектов строительства важных гражданских сооружений и др.) достигнуты определенные результаты, имеющие как теоретическое, так и практическое значение.

Усилиями тектонофизиков России в ИФЗ РАН за последние годы возобновлено проведение Всероссийских тектонофизических конференций (2008, 2012 гг.), организованы регулярные молодежные тектонофизические школы-семинары (2009, 2011, 2013 гг.). Эти важные события дали возможность краткого обобщения основных результатов полевых тектонофизических исследований, достигнутых за 60 лет. Следует подчеркнуть, что в предлагаемой обзорной работе автор ни в коей мере не претендует на исчерпывающее рассмотрение хотя бы большинства работ по изучению тектонических напряжений с помощью геологических индикаторов; в настоящей статье приведены результаты лишь наиболее крупных региональных работ, а также теоретических и практических тектонофизических исследований.

\section{2. РЕКОНСТРУКЦИЯ ПАЛЕОНАПРЯЖЕНИЙ ПО ТРЕЩИНОВАТОСТИ И МЕЛКИМ СТРУКТУРНЫМ ФОРМАМ}

На ранних этапах полевых тектонофизических исследований [Gzovsky, 1954, 1959, 1975] широко использовались массовые замеры трещиноватости для выделения сколовых сопряженных трещин. Метод основан на представлениях теории прочности Кулона, согласно которой разрушение материала и образование разрыва связываются с плоскостью действия максимальных касательных напряжений. Положение сколовых трещин может отличаться от плоскостей действия максимальных касательных напряжений на угол скалывания $\alpha$. Эти трещины расположены симметрично относительно осей главных нормальных напряжений - максимальных сжимающих ( $\sigma_{3}-$ «ось сжатия») и минимальных сжимающих ( $\sigma_{1}-$ «ось растяжения»). При этом угол между сопряженными трещинами и осью сжатия составляет $45^{\circ}-\alpha$, а с осью растяжения $45^{\circ}+\alpha$. Промежуточная ось $\sigma_{2}$ совпадает с линией пересечения сопряженных сколов. Результаты выполненной реконструкции осей главных нормальных напряжений и анализа мелких структурных форм приведены на рис. 1.

Основной проблемой при использовании метода сопряженных сколов являлось объективное выделение одновозрастных сколов. Существенный вклад в эту методику был внесен П.Н. Николаевым, предложившим учитывать разброс максимумов сколов, возникающий в процессе одноэтапного деформирования. Образование новых сколов на этом этапе при неизменной ориентации осей напряжений приводит к развороту ранних трещин, что вызывает асимметрию распределения трещин единой системы [Nikolaev, 1977]. Методы выделения сколовых сопряженных трещин дают возможность определять ориентировку осей главных нормальных напряжений, а прочие структурные формы - геодинамическую обстановку деформирования: наличие жил, даек различного состава и возраста - обстановку растяжения, мелких изоклинальных складок, кливажа - сжатия.

На основе детального изучения тектоники Байджансайского антиклинория и реконструкции тектонических напряжений по сколовым трещинам М.В. Гзовский [Gzovsky, 1959, 1963] пришел к выводу о механизме формирования складок I порядка антиклинория 
как складок поперечного изгиба без существенного изменения мощности. При этом большинство дополнительных складок сформировалось под действием сжимающих усилий вдоль слоистости в течение одной или нескольких фаз одновременно с ростом крупных основных складок 1 и 2-го порядка. Механизмы формирования более мелких складок включают в себя продольное расплющивание (при увеличении мощности слоя), продольный изгиб (путем изгибания слоя без существенного изменения мощности), выжимание материала и др. [Gzovsky, 1963].

Одним из первых после М.В. Гзовского в 1979 г. Г.С. Гусевым была составлена карта тектонических напряжений со схемой динамических районов и систем разломов на западе Верхояно-Чукотской складчатой области (рис. 2). Карта и схема были созданы на основе реконструкции 420 локальных стресс-состояний и анализа ориентировок кливажа, ориентировки борозд скольжения, даек, минеральных жил, элементов складчатости [Gusev, 1979]. Анализ ориентировок осей тектонических напряжений, складчатых и разрывных структур показал, что основным механизмом формирования структур региона является продольный изгиб в условиях горизонтального сжатия. Складчатые структуры продольного изгиба разделены автором на три кинематических типа и семь кинематических разновидностей.

С помощью перечисленных выше геологических индикаторов восстанавливались тектонические напряжения рядом авторов [Nikolaev, 1977; Sherman, Dneprovsky, 1989; Gladkov et al., 2008; Lunina, Gladkov, 2008; Umurzakov, 2009].

Вскоре после работы Г.С. Гусева [Gusev, 1979] в 80-х годах прошлого века были предложены отдельные методы реконструкции тектонических напряжений, основанные на более формализованном анализе комплекса мелких структурных форм [Rastsvetaev, 1982; Gintov, Isai, 1984a, 1984b]. Крупными работами по реконструкции тектонических напряжений перечисленными методами являются тектонофизические работы по Украинскому щиту [Gintov, Isai, 1984a, $1984 b]$, схемы ранговых тектонических напряжений Кавказа и Восточно-Европейской платформы [Nikolaev, 1992].

Результаты реконструкции полей тектонических напряжений, восстановленных геолого-структурными методами, и увязка их с механизмами очагов землетрясений, производившаяся для различных территорий Байкальской рифтовой зоны (БРЗ) разными авторами в 1973-1984 гг., представлены в обобщенном виде в работе [Sherman, Dneprovsky, 1989]) (рис. 3). Основные выводы этих исследований следующие: для БРЗ характерно северо-западное субгоризонтальное растяжение, при этом в центральной части оси сжатия ориентированы вертикально или наклонно в северо-восточном направлении, тип региональных напряжений - сдвигораздвиговый и раздвиговый; на флангах БРЗ проявле- ны сдвиговый и сдвиго-раздвиговый типы полей напряжений с субгоризонтальной или пологой ориентацией оси сжатия, простирающейся в северо-восточном направлении. Региональные поля тектонических напряжений, реконструированные геолого-структурными методами, полностью совпадают с полями тектонических напряжений механизмов очагов землетрясений с $M \geq 51 / 2$.

Особым индикатором тектонических напряжений являются трещины отрыва, морфология поверхностей которых дала возможность П. и Е. Банквитцам предложить фрактографический метод реконструкции палеонапряжений [Bankwitz P., Bankwitz E., 1984]. Уникальный опыт применения этого метода позволил П. Банквитцу по трещинам в керне глубинного континентального бурения в Баварии (скважина КТВ) установить особенности палеонапряжений, зафиксированных в пробуренных породах, и тот факт, что условия хрупкого разрушения в настоящее время проявляются и господствуют до глубины 9 км [Bankwitz, 2000].

\section{3. РЕКОНСТРУКЦИЯ ПАЛЕОНАПРЯЖЕНИЙ ПО БОРОЗДАМ СКОЛЬЖЕНИЯ}

Существенный прорыв в исследовании тектонических напряжений по геологическим индикаторам был осуществлен при развитии методов, основанных на измерении и анализе векторов тектонических перемещений на зеркалах скольжения (кинематический, катакластический и другие методы) [Gushchenko, 1973, 1979; Angelier, 1975; Korchemagin, Emets, 1982; Rebet$s k y, 1997]$. Обоснование кинематического метода опирается на теорию дислокационного скольжения Батдорфа-Будянского и содержит три основные предпосылки, сформулированные в кинематическом методе [Gushchenko, 1973]: «Упругопластическое деформирование в заданном «однородноосном» поле напряжений в геологической среде происходит как за счет смещений по вновь образующимся поверхностям трещин (разрывов), так и за счет перемещений по уже существующим ослабленным сечениям различного возраста и генезиса; каждое смещение вызывает возмущение поля напряжений только более мелкого масштабного уровня, а исходное поле напряжений остается неизменным; направление смещения вдоль всей поверхности плоскости сместителя совпадает с направлением касательного напряжения на этой плоскости и отвечает заданному полю напряжений. Важным условием применимости кинематического метода является положение о том, что борозды скольжения отражают следы последних наиболее молодых тектонических смещений, при этом следы более ранних смещений или стираются, или имеют худшую сохранность».

Для доказательства молодого возраста восстановленных по бороздам скольжения тектонических напряжений в 1976 г. О.И. Гущенко произвел испытание 

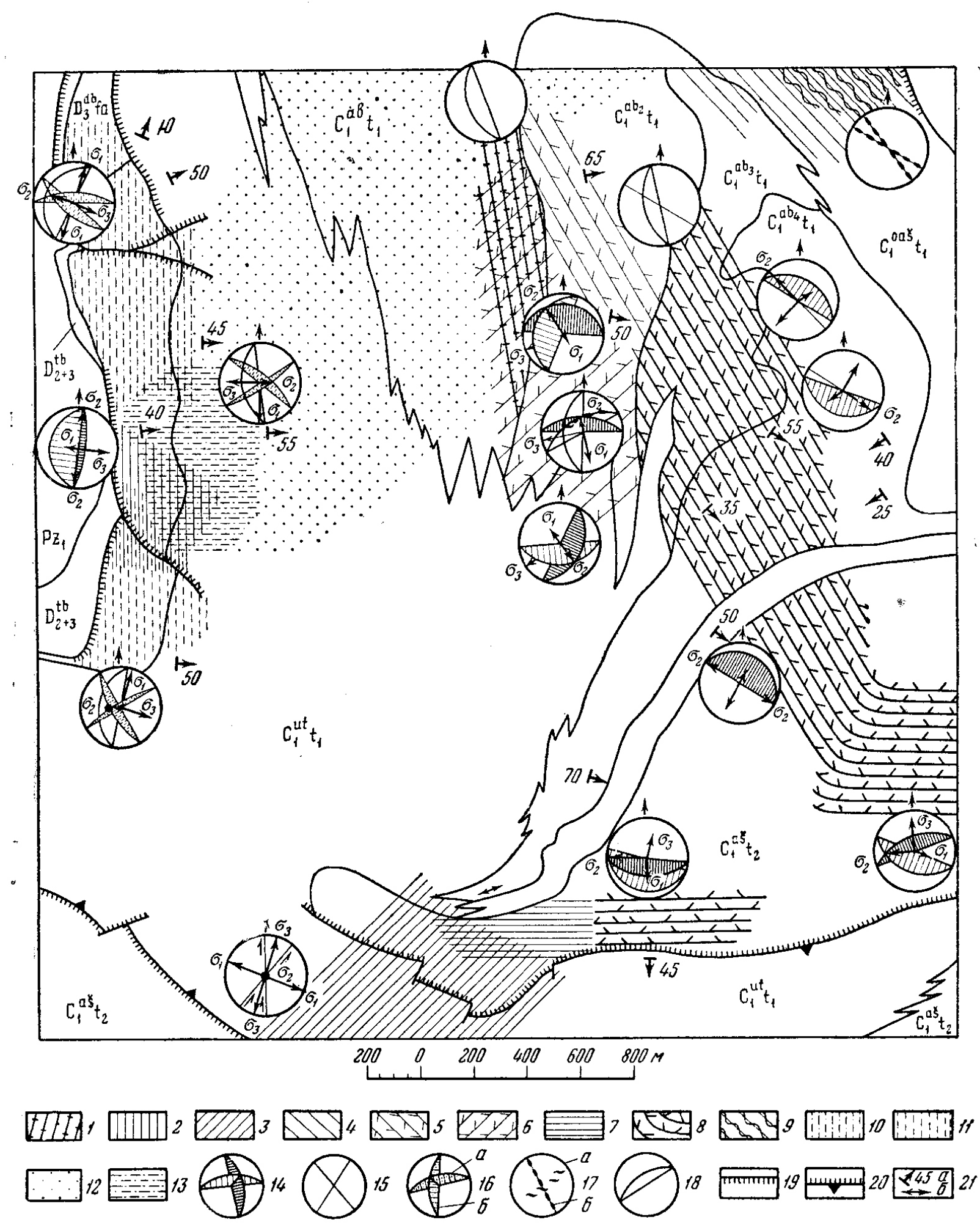

кинематического метода на 600-м горизонте рудника Расвумчорр (Хибины, Кольский п-ов), где проводились инструментальные измерения in situ современных напряжений. Сопоставление восстановленного локального стресс-состояния показало удовлетворительную корреляцию с данными инструментальных измерений (рис. 4), подтверждающую молодой возраст действующих в массиве напряжений, приводящих к формиро- ванию борозд скольжения [Markov, 1977; Gushchenko, 1979]. Нижний возрастной рубеж обычно устанавливается с привлечением имеющихся в исследуемом районе геологических данных [Vasilyev et al., 2002]. Чаще всего возраст восстанавливаемых по бороздам скольжения тектонических напряжений принимается за неотектонический [Sim, 1991].

Анализ борозд скольжения дает возможность рас- 
Рис. 1. Схематическая карта господствующей трещиноватости Айлимбайской синклинали и восточного окончания Мынчабырской антиклинали [Gzovsky, 1963].

Системы трещиноватости, возникшей при действии только сжимающих напряжений: 1 - кливаж, возникший при сжатии, перпендикулярном слоистости; 2 - трещины и мелкоамплитудные смещения, возникшие при горизонтальном направлении оси $\sigma_{3}$, ориентированной вкрест простирания наклонных слоев, ось $\sigma_{2}$ горизонтальна; 3 - трещины и мелкоамплитудные смещения, возникшие при горизонтальном направлении оси $\sigma_{3}$, ориентированной вкрест простирания наклонных слоев, ось $\sigma_{2}$ вертикальна; 4 - трещины и мелкоамплитудные смещения, возникшие при горизонтальном направлении оси $\sigma_{3}$, ориентированной вкрест простирания наклонных слоев, ось $\sigma_{2}$ имеет различное направление (неустойчива); 5 - трещиноватость, возникшая при горизонтальном направлении оси $\sigma_{3}$, ориентированной наискось к простиранию наклонных слоев, ось $\sigma_{2}$ вертикальна; 6 - трещиноватость, возникшая при горизонтальном направлении оси $\sigma_{3}$, ориентированной наискось к простиранию наклонных слоев, ось $\sigma_{2}$ имеет различное направление (неустойчива); 7 - трещиноватость, возникшая при наклонном направлении оси $\sigma_{3}$, ориентированной наискось к простиранию наклонных слоев, ось $\sigma_{2}$ почти горизонтальна; 8 - кливаж, возникший при наклонном направлении оси $\sigma_{3}$, ориентированной наискось к простиранию наклонных слоев, ось $\sigma_{2}$ почти горизонтальна; 9 - интенсивная разлинзованность пород наискось к простиранию слоев. Системы трещиноватости, при возникновении которой могли действовать как сжимающие, так и растягивающие напряжения: 10 - трещины и мелкоамплитудные смещения, возникшие при направлении оси $\sigma_{1}$ вдоль простирания слоев, ось $\sigma_{2}$ почти совпадает с падением слоев; 11 - трещины и мелкоамплитудные смещения, возникшие при направлении оси $\sigma_{1}$ вдоль простирания слоев, ось $\sigma_{2}$ имеет более крутой наклон, чем слои; 12 - трещины, возникшие при направлении оси $\sigma_{1}$ вдоль простирания слоев, ось $\sigma_{2}$ имеет более крутой наклон, чем слои; 13 - трещины и мелкоамплитудные смещения, возникшие при наклонном направлении оси $\sigma_{1}$, ориентированной вкрест простирания слоев. Стереографические проекции трещиноватости и осей напряжений: 14 - наклонные трещины и кливаж, образовавшиеся при сжатии; 15 - вертикальные трещины и кливаж, образовавшиеся при сжатии; 16 - наклонные трещины, образовавшиеся при растяжении (а), наклонные трещины, обстановка образования которых неясна (б); 17 - кулисообразные ряды трещин отрыва (а) и направление вертикальной разлинзованности (б); 18 - залегание слоистости. Остальные обозначения: 19 - вертикальные разрывные смещения, штрихи стоят при опущенном крыле; 20 наклонные разрывные смещения, треугольник указывает направление наклона; 21 - падение слоев (а), простирание слоев при вертикальном залегании (б). Фации (приведены с сокращением): $\mathrm{C}_{1}{ }_{1} \mathrm{s̆}_{2}-$ ашасайская, тонкослоистые песчанистые известняки и известковистые песчаники; $\mathrm{C}_{1}{ }^{\mathrm{ut}} \mathrm{t}_{1}-$ узунтасская, массивные известняки и доломиты; $\mathrm{C}_{1}{ }^{\mathrm{ab}} \mathrm{t}_{1}-$ айлимбайская, тонкослоистые песчанистые известняки,

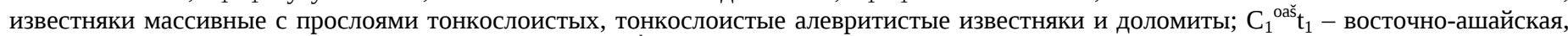
массивные и слоистые известняки и конгломераты; $\mathrm{D}_{3}{ }^{\mathrm{tb}} \mathrm{fa}-$ дарбазинская, разнослоистые известняки, доломиты, песчаники и конгломераты; $\mathrm{D}_{2+3}{ }^{\mathrm{ab}}$ - тюлькубасская свита, пестроцветные песчаники и конгломераты; $\mathrm{Pz}_{1}-$ граувакковые песчаники. $\sigma_{1}, \sigma_{2}, \sigma_{3}-$ направления главных нормальных напряжений.

Fig. 1. Schematic map of dominant fracturing at the Aylimbayskaya syncline and the eastern termination of the Mynchabyrskay anticlyne [Gzovsky, 1963].

Legend: Fracture systems formed due to compressive stresses of one type: 1 - cleavage resulting from compression perpendicular to bedding; 2 fractures and small-amplitudes displacements that occurred with horizontal direction of axis $\sigma_{3}$ oriented across the strike of inclined layers, and horizontal axis $\sigma_{2} ; 3$ - fractures and small-amplitudes displacements that occurred with horizontal direction of axis $\sigma_{3}$ oriented across the strike of inclined layers, and vertical axis $\sigma_{2} ; 4$ - fractures and small-amplitudes displacements that occurred with horizontal direction of axis $\sigma_{3}$ oriented across the strike of inclined layers, and unstable axis $\sigma_{2}$ (variable direction); 5 - fracturing with horizontal direction of axis $\sigma_{3}$ oriented diagonally to the strike of inclined layers, and vertical axis $\sigma_{2} ; 6$ - fractures with horizontal direction of axis $\sigma_{3}$ oriented diagonally to the strike of inclined layers, and unstable axis $\sigma_{2}$ (variable direction); 7 - fracturing with inclined axis $\sigma_{3}$ oriented diagonally to the strike of inclined layers, and almost horizontal axis $\sigma_{2} ; 8$ - cleavage with inclined axis $\sigma_{3}$ oriented diagonally to the strike of inclined layers, and almost horizontal axis $\sigma_{2} ; 9$ - intensive rock boudinage diagonally to the strike of layers. Fracture systems that formed when both compression and extension stresses might be active: 10 - fractures and small-amplitudes displacements that occurred with direction of $\sigma_{1}$ along the strike of layers, and axis $\sigma_{2}$ almost coinciding with layers' dip; 11 - fractures and small-amplitudes displacements that occurred with direction of $\sigma_{1}$ along the strike of layers, and axis $\sigma_{2}$ almost coinciding with layers' dip; 12 - fractures that occurred with direction of $\sigma_{1}$ along the strike of layers, and axis $\sigma_{2}$ steeper than layers; 13 - fractures and small-amplitudes displacements that occurred with inclined axis $\sigma_{1}$ oriented across the strike of layers. Stereographic projections of fracturing and stress axes: 14 - inclined fractures and cleavage due to compression; 15 - vertical fractures and cleavage due to compression; 16 - inclined fractures due to extension (a), and inclined fractures which formation conditions are not clear (б); 17 - echelon series of separation fractures (a), and vertical direction of boudinage (б); 18 - bedding of rock stratification. Other symbols: 19 - vertical discontinuities, dashed lines in case of subsided wing; 20 - sloped displacements due to fracturing, triangles show slope directions; 21 - dip of layers (a), and strike of layers in case of vertical bedding (б). Facies (reduced list): $\mathrm{C}_{1}{ }^{\mathrm{as}} \mathrm{t}_{2}-$ Ashasaiskaya suite, thinly laminated sandy limestone and limy sandstone; $\mathrm{C}_{1}{ }^{\mathrm{ut}} \mathrm{t}_{1}-\mathrm{Uzuntasskaya}$ suite, massive limestone and dolomite; $\mathrm{C}_{1}{ }^{\mathrm{ab}} \mathrm{t}_{1}$ - Aylimbayskaya suite, thinly laminated sandy limestone, massive limestone interbedded with thinly laminated limestone, thinly laminated aleurolite limestone and dolomite; $\mathrm{C}_{1}{ }^{{ }^{t} \mathrm{t}_{1}}$ - East-Ashaiskaya suite, massive and laminated limestone and conglomerate; $\mathrm{D}_{3}{ }^{\text {tb }} \mathrm{fa}$ - Darbazinskaya suite, multilayered limestone, dolomite, sandstone and conglomerates; $\mathrm{D}_{2+3}{ }^{\text {ab }}-$ Tyulkubasskaya suite, multicoloured sandstones and conglomerates; $\mathrm{Pz}_{1}$ - graywacke sandstones; $\sigma_{1}, \sigma_{2}, \sigma_{3}$ - directions of principal normal stresses.

считать коэффициент Лоде-Надаи, характеризующий вид напряженного состояния, оси деформаций, позволяет выделять этапы и фазы деформировании [Gushchenko, 1973, 1999; Vasiliev et al., 1999; Vasiliev, Mostryukov, 2001], сепарацию сколов по энергетическому вкладу в реализацию тектонических напряжений [Rebetsky, 1997]. Перечисленные параметры суще- ственно расширяют информативность результатов реконструкции тектонических напряжений. Использование борозд скольжения дает возможность решать более корректно теоретические проблемы механизмов формирования структур и региональные задачи, связанные с характером напряженно-деформированного состояния среды [Korchemagin et al., 2000]. 


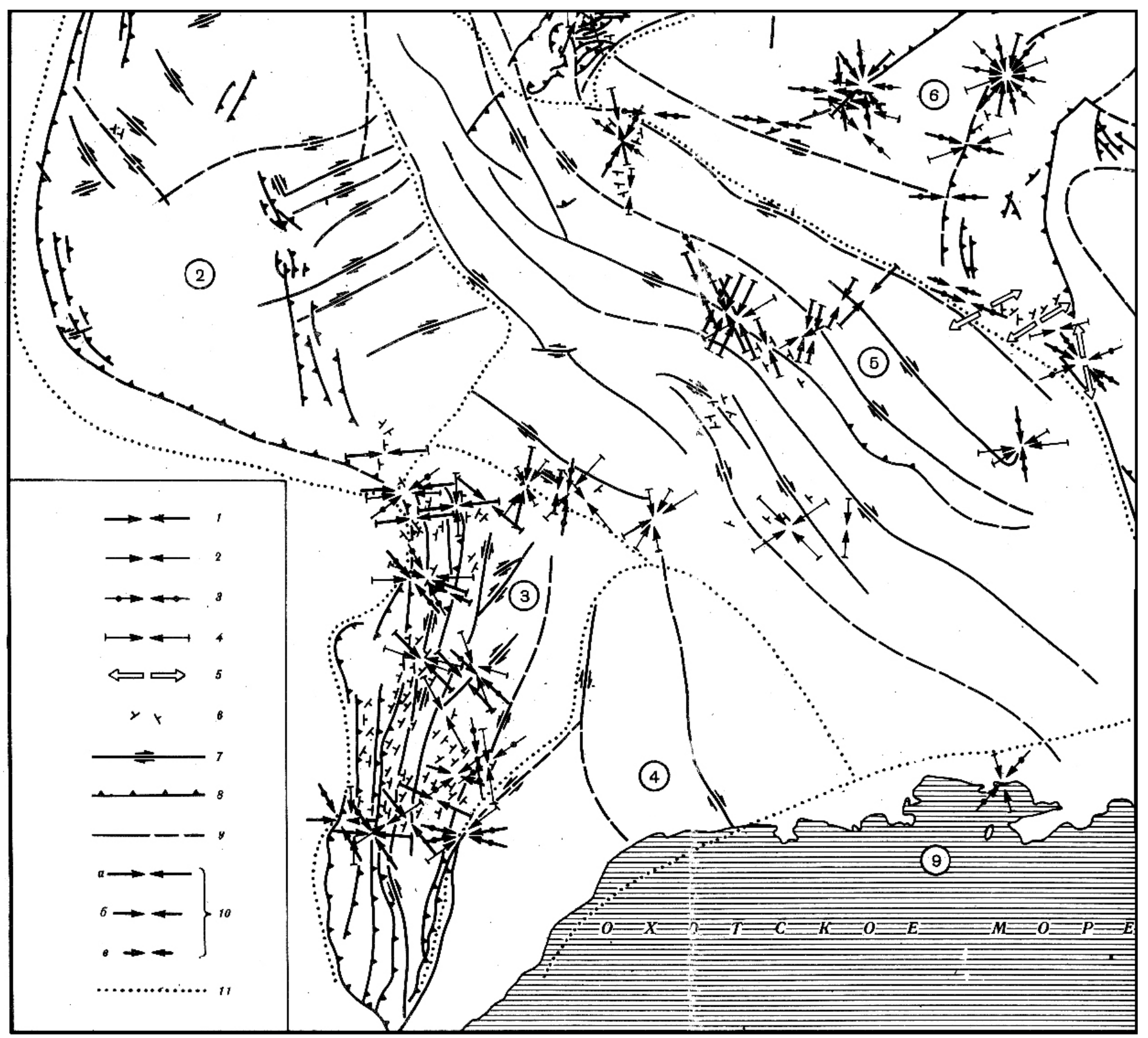

Рис. 2. Схема тектонических полей напряжений Верхояно-Колымской складчатой системы [Gusev, 1979].

1-4 - векторы сжатия: 1 - главные, 2 - второстепенные, 3 - во взбросовых полях напряжений, 4 - в сдвиговых полях напряжений; 5 векторы растяжения в сбросовых полях напряжений; 6 - элементы залегания кливажа; 7 - сдвиги; 8 - взбросы и надвиги; 9 - разломы с неустановленной кинематикой и предполагаемые; 10 - наклон векторов (см. знаки 1-5), выраженные разной длиной стрелок: 0-15 (а), 15-30 (б), более 30 (в); 11 - границы динамических районов, цифры в кружках: 2 - Верхоянский, 3 - Южно-Верхоянский, 4 - Охотский, 5 - Индигиро-Колымский, 6 - Колымо-Омолонский, 9 - Охотско-Чукотский (Приохотский).

Fig. 2. Scheme of tectonic stress fields of the Verkhoyano-Kolyma fold system [Gusev, 1979].

Legend: 1-4 - compression vectors; 1 - main, 2 - secondary, 3 - in reverse stress fields, 4 - in shear stress fields; 5 - extension vectors in normal stress fields; 6 - cleavage bedding elements; 7 - shear faults; 8 - reverse and thrust faults; 9 - faults of unknown kinematics and supposed faults; 10 - slopes of vectors (see symbols 1 to 5 ) shown as arrows of different lengths: $0-15^{\circ}$ (а), $15-30^{\circ}$ (б), over $30^{\circ}$ (в); 11 - boundaries of dynamic areas; numbers in circles: 2 - Verkhoyansky, 3 - South-Verkhoyansky, 4 - Okhotsky, 5 - Indigirka-Kolymsky, 6 - Kolyma-Omolonsky, 9 - Okhotsk-Chukotsky (Priokhotsky). 


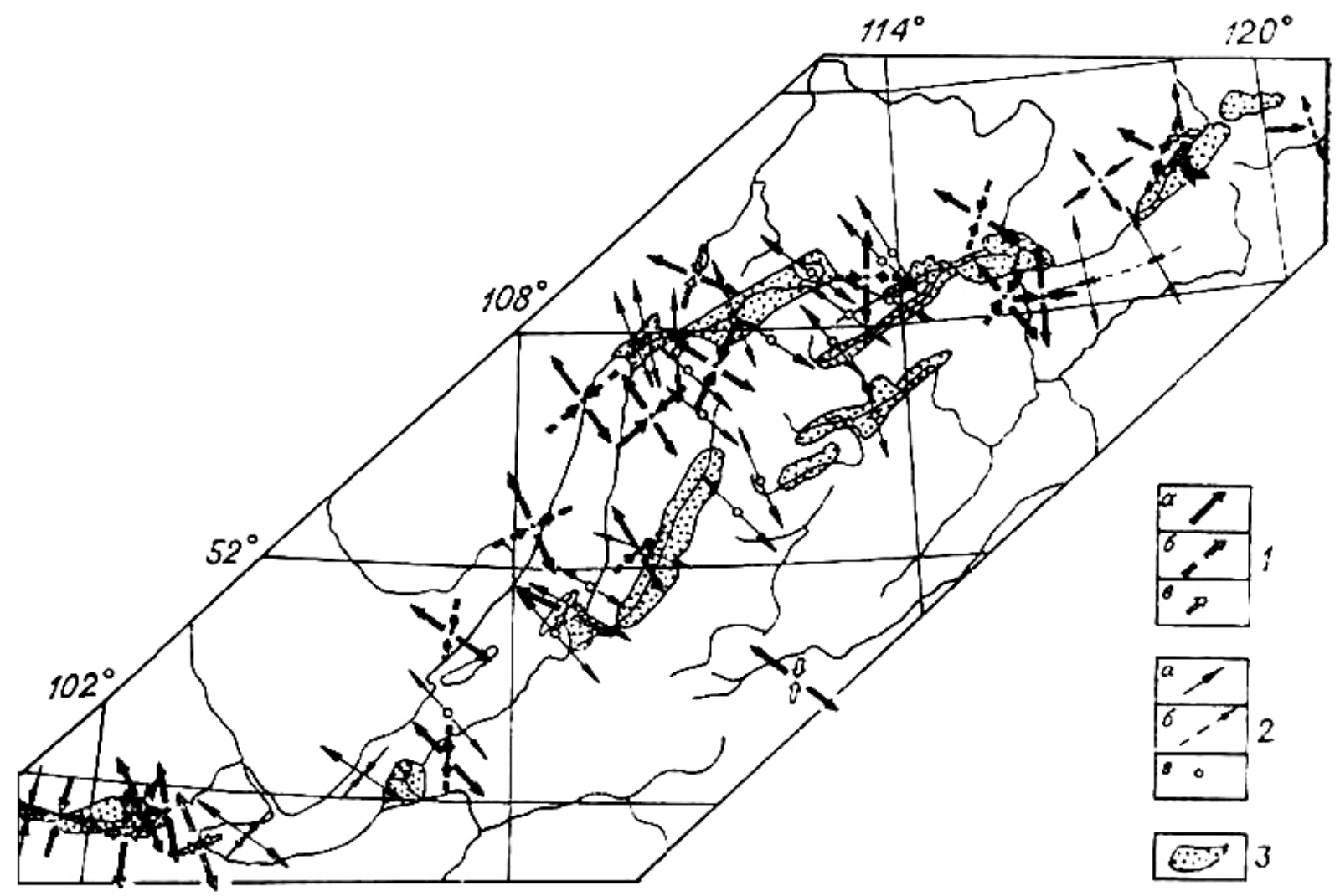

Рис. 3. Схема региональных тектонических напряжений Байкальской рифтовой зоны (по геолого-структурным и сейсмологическим данным).

Составили: С.И. Шерман, Ю.И. Днепровский, В.А. Саньков [Sherman, Dneprovsky, 1989]. 1 - ориентация векторов регионального поля напряжений по геолого-структурным данным (а - горизонтальная, б - наклонная, в - вертикальная); 2 - ориентация векторов поля напряжений по сейсмологическим данным (а - горизонтальная, б - наклонная, в - вертикальная); 3 - кайнозойские впадины и депрессии.

Fig. 3. Scheme of regional tectonic stresses of the Baikal rift zone (from geological, structural and seismological data).

Consolidated by S.I. Sherman, Yu.I. Dneprovsky, V.A. San'kov [Sherman, Dneprovsky, 1989 ]. Legend: 1 - orientations of regional stress field vectors from geological and structural data (a - horizontal, 6 - inclined, в - vertical); 2 - orientations of stress field vectors from seismological data (a - horizontal, 6 - inclined, в - vertical); 3 - Cenozoic basins and depressions.

Один из ранних примеров реконструкции напряженного состояния для крупных регионов кинематическим методом представляют собой работы по Донбассу (рис. 5) [Korchemagin, 1984; Korchemagin, Ryaboshtan, 1987]. На основе значительного фактического материала автор данной статьи выделил этапы формирования специфического внедрения герцинского складчатого сооружения в тело Восточно-Европейской платформы (ВЕП) и последующего его деформирования в альпийский период.

Значительный вклад в тектонофизические исследования полевыми методами внесли работы Ж. Анжелье с коллегами из Тайваня, Исландии, России и других стран [Angelier et al., 1994; Saintot, Angelier, 2002], peконструкции палеонапряжений в различных частях ВЕП [Kopp et al., 1999; Kopp, Tveritinova, 1999; Sim, 2000], северных частей Урала [Sim, 2000], а также исследования тектонических напряжений группой сотрудников МГУ им. М.В. Ломоносова под руковод- ством Л.М. Расцветаева, группой исследователей во главе с М.Л. Коппом (ГИН РАН), исследования Н.Ю. Васильева и А.О. Мострюкова (МГГРУ, ИФЗ РАН), А.В. Парфеевец и В.А. Санькова (ИЗК СО РАН) [Parfeevets, Sankov, 2006], группы Донецкого политехнического университета под руководством В.А. Корчемагина и др.

Крупные исследования палеонапряжений с помощью совместного использования структурно-парагенетического и кинематического методов проведены в Крыму [Gintov, Murovskaya, 2000a, 2000b]. Из большого числа выводов, сделанных авторами, следующие аспекты полевых тектонофизических исследований представляются наиболее важными. 1. Убедительно показано, что тектонофизическое изучение сложнопостроенных геологических систем требует применения разных методов - до- и соскладчатые деформации хорошо выявляются структурно-парагенетическими методами; складчатые и постскладчатые деформации 


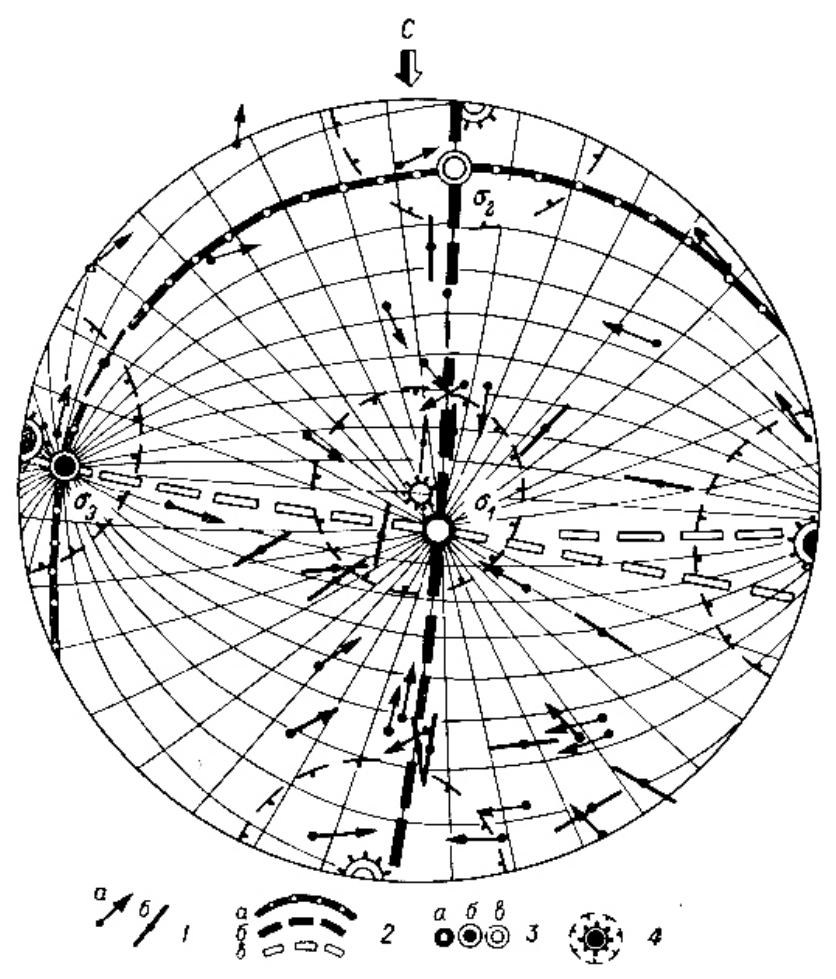

Рис. 4. Кинематическая стереограмма структуры разрушения массива Расвумчоррского месторождения (гор. 600) и ее интерпретация при реконструкции направления внешних, воздействующих на массив, главных нормальных напряжений [Markov, 1977].

1 - направления зафиксированных по бороздам скольжения сдвиговых смещений висячих крыльев нарушений (а - направления однозначные, б - неоднозначные); 2 - след проекции плоскостей действия главных нормальных напряжений $\sigma_{1}(\mathrm{a}), \sigma_{3}$ (б), $\sigma_{2}$ (в); 3 - точки выхода на верхнюю полусферу направлений главных осей напряжений $\sigma_{1}\left(\right.$ a), $\sigma_{3}$ (б), $\sigma_{2}($ в), определенных по кинематическому методу; 4 - точки выхода осей напряжений $\sigma_{1}, \sigma_{2}, \sigma_{3}$, направления которых определены методами разгрузки и ультразвуковым (пунктиром ограничен 20-градусный диапазон вариации этих определений).

Fig. 4. Kinematic stereogram of the destruction pattern of the Rasvumchorrskoe field (hor. 600), and its interpretation in reconstruction of directions of external principal normal stresses [Markov, 1977].

Legend: 1 - directions of shear displacements recorded from slikensides at hanging walls of discontinuities (a - unambiguously determined directions, $\sigma$ - ambiguous directions); 2 - traces of projections of principal normal stress planes for $\sigma_{1}\left(\right.$ (а), $\sigma_{3}$ (б), $\sigma_{2}$ (в); 3 - output points of principal stress axes on the upper hemisphere for $\sigma_{1}(\mathrm{a}), \sigma_{3}(б), \sigma_{2}(\mathrm{~B})$, according to the kinematic method; 4 - output points of stress axes $\sigma_{1}, \sigma_{2}, \sigma_{3}$, which directions are determined by the stress-release and ultrasound methods (the dotted line marks the $20^{\circ}$ range of variations of determined values).

эффективнее изучать кинематическими методами, т.е. сделан еще один шаг в методике изучения палеотектонических напряжений полевыми методами. 2. На большом фактическом материале, собранном в процессе 11-летних исследований, выделено 38 этапов деформирования горных пород Крымского п-ова, обусловивших осадконакопление, складкообразование, разрывообразование, формирование орогена, вертикальные и горизонтальные перемещения блоков, вулканизм. Разные этапы сопровождались разным характером действовавших сил. 3. Показано, что деформационные процессы происходили с постоянно меняющимся соотношением главных нормальных напряжений, причем чаще всего они начинались или заканчивались при коэффициенте Лоде-Надаи $\mu \sigma$, равном примерно +1 или -1 , переходя через нулевое значение $\mu \sigma$. Это вызвано изменением величин главных нормаль- ных напряжений в процессе деформирования. Вывод о чередовании этапов деформирования с изменением коэффициента $\mu \sigma$, полученный при независимых исследованиях разными методами примерно в одно время ([Vasiliev et al., 1999; Vasiliev, Mostryukov, 2001; Gushchenko, 1999; Gushchenko et al., 2001], эти работы будут рассмотрены ниже), крайне важен и повышает объективность оценки характеристик тектонических напряжений, реконструируемых по геологическим индикаторам. Ранее вывод о смене $\mu \sigma$ от +1 до -1 отмечен в работе автора в связи с прогнозом гнезд горного хрусталя на Приполярном Урале и будет обсуждаться ниже [Sim, 1982, 2000].

Необходимо отметить, что изучение тектонических напряжений по векторам перемещений на зеркалах скольжения привело к выводам о некоторых специфических особенностях деформирования объемов горных 


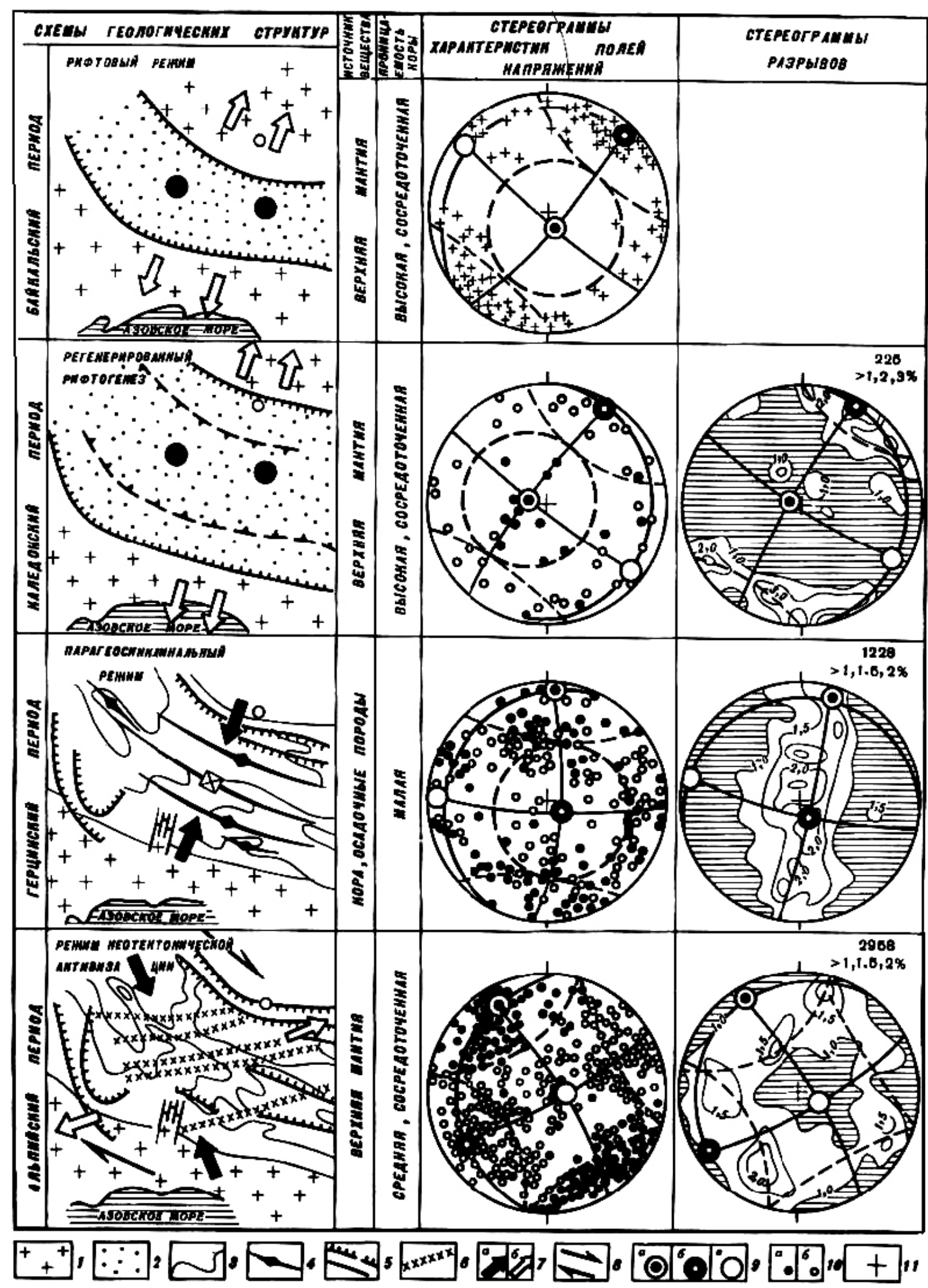

Рис. 5. Развитие структуры и поля напряжений Донбасса [Korchemagin, 1984; Korchemagin, Ryaboshtan, 1987].

1 - фундамент; 2 - верхнепротерозойские осадки; 3 - известняки карбона; 4 - оси антиклиналей; 5 - разломы; 6 - структурно-морфологические зоны; 7 - активные усилия: сжатия (а) и растяжения (б); 8 - направление сдвигания. На стереограммах: 9 - проекции осей $\sigma_{3}($ a), $\sigma_{1}\left(\right.$ б), $\sigma_{2}\left(\right.$ в) регионального уровня; $10-\sigma_{3}\left(\right.$ a), $\sigma_{1}($ б) локального уровня; 11 - полюсы даек протерозоя (на стереограмме в верхнем ряду).

Fig. 5. Development of the structure and the stress field of Donbass [Korchemagin, 1984; Korchemagin, Ryaboshtan, 1987].

Legend: 1 - base; 2 - Upper Proterozoic sediments; 3 - Carbon limestone; 4 - axes of anticlines; 5 - faults; 6 - morphological structural zones; 7 - active compression (а) and extension (б); 8 - shear direction. Stereograms: 9 - projections of axes $\sigma_{3}\left(\right.$ (а), $\sigma_{1}\left(\right.$ б), $\sigma_{2}$ (в) of the regional level; 10 projections of axes $\sigma_{3}(\mathrm{a}), \sigma_{1}($ (б) of the local level; 11 - poles of Proterozoic dykes (top raw in the stereogram). 
пород, прошедших неоднократное деформирование в разных полях напряжений. Реализация перемещений в таких горных породах зависит от их физических свойств и неоднородностей разного масштаба и генезиса. Так, максимумы реализованных плоскостей $\left(\tau_{\text {реал, }}\right.$ т.е. плоскостей с бороздами скольжения) в молодом (последнем?) поле напряжений часто совпадают лишь с одной из плоскостей действия $\tau_{\max }$, в то время как другие могут быть приурочены либо к плоскости действия $\tau_{1}$ (плоскости, обусловленные разностью между величинами $\sigma_{2}$ и $\sigma_{3}$ ), либо к $\tau_{3}$ (плоскости, обусловленные разностью между величинами $\sigma_{2}$ и $\sigma_{1}$ ) в зависимости от предыстории деформируемого массива. Более того, вопреки теоретическим представлениям, повсеместно наблюдаются смещения по многочисленным плоскостям сланцеватости, которые нормальны к оси сжатия. Это вызвано наличием на этих плоскостях минералов группы листовых силикатов, что обеспечивает наименьший коэффициент трения на них и благоприятные условия для перемещения по ним, несмотря на их «неудобную» ориентацию к осям главных нормальных напряжений. Отмечены также случаи, когда большинство плоскостей с бороздами скольжения формируется на плоскостях, параллельных оси растяжения. Этот феномен, вероятно, связан с тем, что такие плоскости минимально раскрыты при одноосном растяжении и из-за большего трения на них, чем на прочих плоскостях, борозды на них видны лучше [Sim, 2012]. Перечисленные особенности приводят к выводу о том, что при выделении сопряженных сколовых трещин велика вероятность ошибки нахождения псевдосопряженных пар сколовых трещин. Наиболее уверенно они могут выделяться в молодых по возрасту породах, прошедших одну стадию деформирования, либо в породах, испытавших относительно молодой метаморфизм, преобразовавший или залечивший трещины предыдущих этапов деформирования.

\section{4. ВЫДЕЛЕНИЕ ФАЗ В ЕДИНОМ ЦИКЛЕ ДЕФОРМИРОВАНИЯ}

На базе данных об ориентировках векторов перемещения на зеркалах скольжения разработаны принципы выделения фаз в едином цикле деформирования [Vasiliev et al., 1999; Vasiliev, Mostryukov, 2001; Gushchenko, 1999; Gushchenko et al., 2001; Leonov et al., 2001; Petrov et al., 2008]. В основной алгоритм выделения фаз деформирования заложен постулат непрерывности деформационных процессов во времени, согласно которому «в ходе деформационных тектонических процессов девиаторная часть тензора макроскопических значений (D) не достигает нулевых значений, т.е. $\mathrm{D} \neq 0$; ось $\sigma_{1} \neq \sigma_{3} »$. В силу этого постулата «... отрицается возможность достижения равенства между предельными по величине главными напряжениями $\sigma_{1}$ и $\sigma_{3}$, а следовательно, и одного из вариантов переиндексации во времени главных осей $\sigma_{1}$ на $\sigma_{3}$ и наоборот»
[Gushchenko, 1999, p. 114-115]. В ходе непрерывных процессов происходит циклическая переиндексация главных осей напряжений. В едином этапе деформирования выделяется шесть фаз с сохранением «каркаса» ориентировок главных нормальных напряжений с их закономерной переиндексацией. Последовательность фаз деформирования определяется величиной дисперсии ориентировок векторов $\tau_{n}$ относительно осей главных нормальных напряжений - чем древнее деформационная фаза, тем дисперсия больше из-за разворота плоскостей $\tau_{n}$ при последующем деформировании. Кроме этого, наиболее молодая фаза должна включать в себя наибольшее число плоскостей $\tau_{n}$ из-за их лучшей сохранности. Переиндексация главных нормальных напряжений в ходе деформирования отмечалась еще в работе А.В. Пэка [Pack, 1947]. М.В. Гзовским в складчато-разрывных структурах Баджансайского антиклинория были выделены два главных поля напряжений и четыре - промежуточных между ними; выделенные поля характеризовались переиндексацией осей главных нормальных напряжений и видом напряженного состояния с выделением полей с преобладающей обстановкой растяжения и, напротив, обстановкой сжатия [Gzovsky, 1963, p. 352-353]. Эта же особенность деформирования с переиндексацией осей главных нормальных напряжений (деформаций) при так называемом моделировании «в условиях плоского деформированного состояния» неоднократно наблюдалась при физическом моделировании (ось средних деформаций $\mathrm{E}_{2}$ менялась местами с осью $\mathrm{E}_{1}$ или $\mathrm{E}_{3}-$ А.В. Михайлова, устное сообщение). Таким образом, факт присутствия переиндексации осей главных нормальных напряжений (деформаций) в процессе деформирования эмпирически установлен независимыми исследованиями. Принципиально новым является обоснование закономерности в процессе смены наименования осей и формулировка границ фаз при непрерывном деформировании, которые характеризуются меняющимся видом напряженного состояния между алгебраически максимальными значениями коэффициента Лоде-Надаи $\mu \sigma=1$ и алгебраически минимальными $\mu \sigma=-1$. Между фазами с $\mu \sigma=+1$ (одноосное сжатие) до $\mu \sigma=-1$ (одноосное растяжение) вид напряженного состояния проходит стадию сдвига с $\mu \sigma=0$, соответственно смена двух взбросовых фаз меняется на две сбросовых через сдвиговую фазу. Пары взбросовых и сбросовых полей отличаются друг от друга взаимно ортогональными горизонтальными осями $\sigma_{3}$ и, соответственно, $\sigma_{1}$ (рис. 6) [Vasiliev, Mostryukov, 2001].

Согласно О.И. Гущенко, чем больше абсолютное значение $\mu \sigma$, тем выше может быть скорость деформирования за счет конического распределения плоскостей действия $\tau_{\max }$, обеспечивающего смещение по большому спектру плоскостей в отличие от сдвиговой фазы, когда плоскости действия сводятся к двум площадкам между осями $\sigma_{1}$ и $\sigma_{3}$ [Gushchenko, 1999].

Обоснование возрастной последовательности выде- 


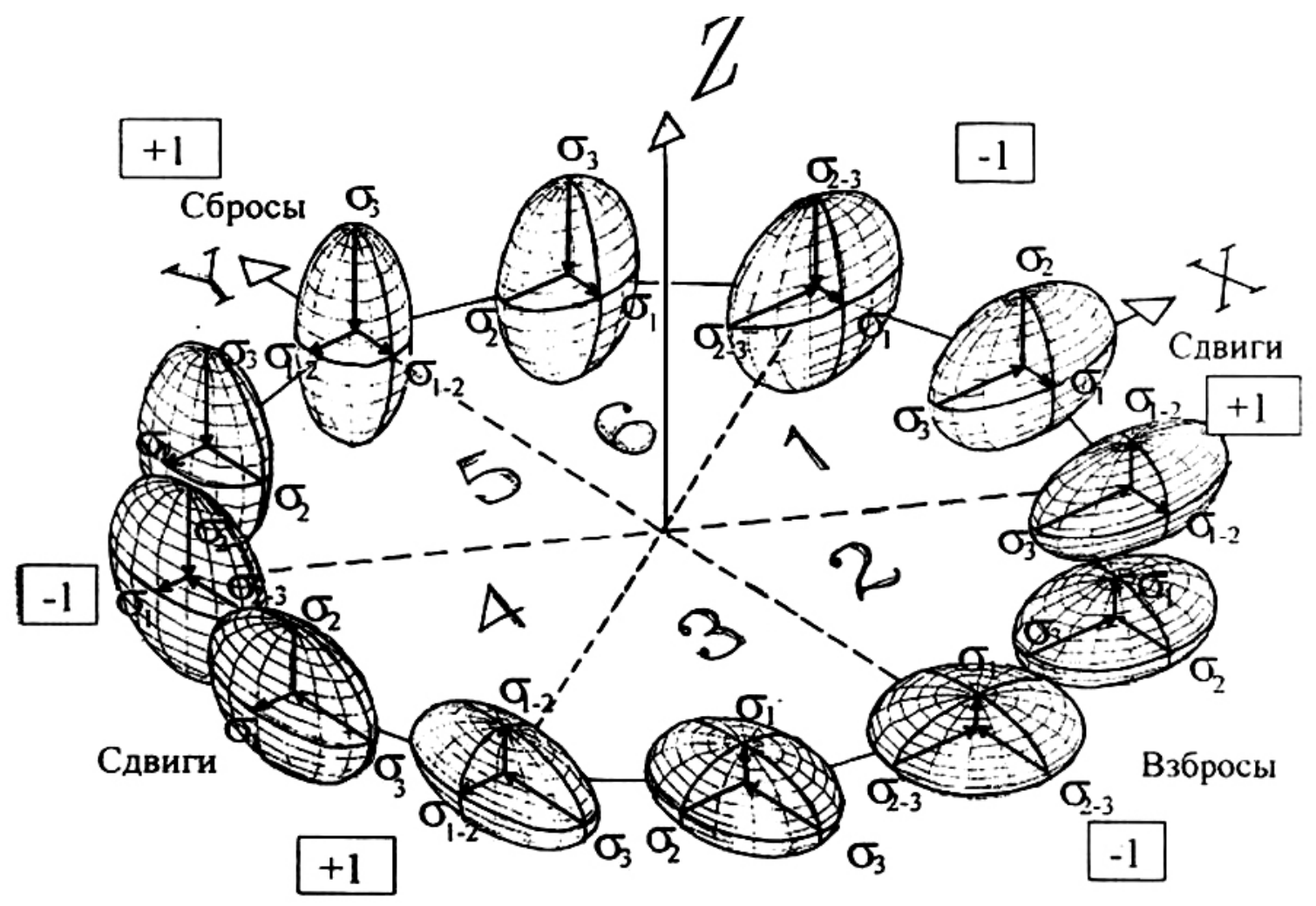

Рис. 6. Схема изменения соотношений между осями $\left(\sigma_{1}{ }^{\mathrm{per}}, \sigma_{2}{ }^{\mathrm{per}}, \sigma_{3}{ }^{\mathrm{per}}\right)$ главных нормальных напряжений в течение цикла деформаций [Vasiliev, Mostryukov, 2001].

X, Y, Z - координаты главных осей тензора напряжений; $\sigma_{1,2,3}$ - оси главных напряжений; 1-6 - фазы цикла деформации.

Fig. 6. Changes of relations between principal stress axes $\left(\sigma_{1}{ }^{\text {per }}, \sigma_{2}{ }^{\text {per }}, \sigma_{3}{ }^{\text {per }}\right)$ through the deformation cycle [Vasiliev, Mostryukov, 2001].

$\mathrm{X}, \mathrm{Y}, \mathrm{Z}$ - coordinates of the principal axes of the stress tensor; $\sigma_{1,2,3}$ - principal stress axes; $1-6$ - phases of the deformation cycle.

ленных фаз деформирования проведено по комплексу данных на примере деформаций в Гальмаэнанском массиве ультрабазитов (Корякское нагорье). Здесь были использованы геологические материалы по ориентировкам систем плоскостей кливажа, элементам залегания контактов габбро, пироксенитов и дунитов, хромитовых прожилков, простираниям границ неотектонических блоков, механизмам очагов землетрясений [Vasiliev et al., 1999; Vasiliev, Mostryukov, 2000].

Для Северного Причерноморья обобщены реконструкции тектонических напряжений как структурно-парагенетическим методом [Rastsvetaev, 1982, 1987], так и методом стресс-мониторинга [Gushchenko, 1999].

Необходимо заметить, что в этом регионе проведено значительное количество тектонофизических исследований по геологическим индикаторам. Так, были исследованы разные этапы деформирования эльджуртинских гранитов (этапы обоснованы по геологическим данным) [Vasilyev et al., 2002]; на основании изучения складок в детачменте Воронцовского покрова и тектонических напряжений кинематическим методом было показано, что покров образовался в результате гравитационного перемещения горных пород [Yakov- lev, Sim, 2007]; проведено сопоставление результатов тектонофизических исследований по геологическим индикаторам, проведенных разными методами структурно-парагенетическим и методом Ж. Анжелье (рис. 7) [Marinin, Saintot, 2008, 2012]. Сравнение результатов, полученных двумя независимыми группами исследователей, показало, что в пределах складчатого сооружения Северо-Западного Кавказа преобладают субгоризонтальные ориентировки максимальных сжимающих напряжений; наиболее четко из них проявлено северо-восточное (до север-северо-восточного) направление, с действием которого связано формирование основных позднеальпийских структур региона; поле напряжений, связанное с север-северо-западным сжатием, было проявлено на позднейшем этапе развития района.

На основании анализа банка данных, состоящего из 23500 замеров направлений векторов перемещений на зеркалах скольжения в 2001 г., выделены шесть фаз деформирования [Gushchenko et al., 2001; Leonov et al., 2001]. Датировка этих фаз опирается на Кавказе на позднеплиоценовый возраст эльджуртинских гранитов и данные по р-ну г. Бештау, на которых выделе- 


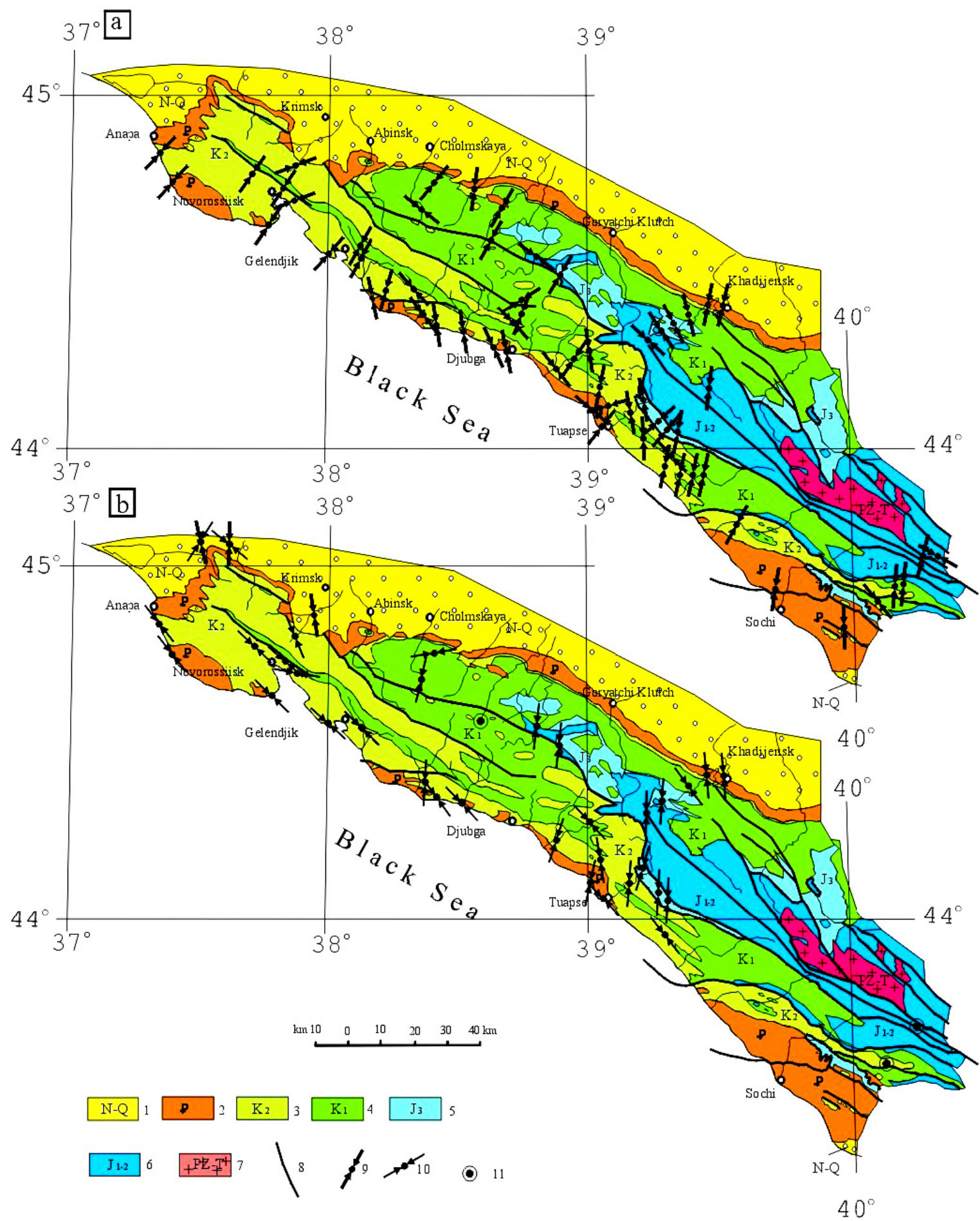

Рис. 7. Схема ориентировки максимальных сжимающих напряжений $\left(\sigma_{3}\right)$ в пределах Северо-Западного Кавказа по материалам российской группы исследователей: $a$ - наиболее проявленных или доминантных (связанных большей частью со складчатым этапом); $b$ - менее проявленных или второстепенных [Marinin, Sainton, 2012].

1-7 области выходов пород: 1 - неогена - антропогена, 2 - палеогена, 3 - верхнего мела, 4 - нижнего мела, 5 - верхней юры (с келловеем), 6 - нижней - средней юры, 7 - палеозоя - триаса; 8 - разрывные нарушения; 9 - ориентировки наиболее проявленных или доминантных направлений осей сжатия; 10 - ориентировки менее проявленных или второстепенных направлений осей сжатия; 11 - субвертикальная оиентировка осей сжатия.

Fig. 7. Scheme of orientations of maximum compression stresses $\left(\sigma_{3}\right)$ within the North-Western Caucasus, according to data collected by the Russian research team: $a$ - most clearly manifested or dominant (mainly associated with the stage of folding); $b$ - less manifested or secondary [Marinin, Sainton, 2012].

1-7 - rock outcrops: 1 - Neogene-Anthropogene, 2 - Paleogene, 3 - Upper Cretaceous, 4 - Lower Cretaceous, 5 - Upper Jurassic (including Callovian), 6 - Lower-Middle Jurassic, 7 - Paleozoic-Triassic; 8 - faults; 9 - orientations of the most clearly manifested or dominant directions of compression axes; 10 - less manifested or secondary directions of compression axes; 11 - subvertical orientations of compression axes. 
ны все шесть фаз деформирования, т.е. возраст всего этапа (цикла) деформирования принят кайнозойским (постпозднеплиоценовым) [Leonov et al., 2001].

Эти фазы позволили разработать двухслойную модель продольно-волнового деформирования указанного региона, согласно которой два однородных слоя верхний более жесткий, упруговязкий (аналог литосферной плиты или коры) и нижний - менее жесткий, вязкопластичный слой (верхняя мантия или низы коры) испытывают проскальзывание друг по другу за счет приложения к подошве верхнего слоя поддвиговых усилий.

Под действием последних на ослабленных участках подошвы плиты преодолеваются силы сцепления, вследствие чего на этих участках развиваются поддвиговые криповые подвижки с возникновением фронтального сжатия и тыльного растяжения по отношению к вектору подвижки. В модели рассматриваются возможные геологические следствия, связанные с волновым распределением деформирования в плите. Совместный критический анализ модели, площадного распространения фаз деформирования и данных по тектоническому строению и геодинамике региона приводит авторов к выводу о том, что «геодинамическая обстановка на территории Скифо-Сарматии может трактоваться как обстановка локализованного или, скорее, рассеянного поддвига в северном направлении, причиной которого служит взаимодействие Большого Кавказа, а в более общем плане - Аравийской плиты с краем плиты Евразии в условиях либо их встречного движения, либо обоюдного движения к северу, но с большей скоростью у Кавказа» [Leonov et al., 2001, p. 56]. Обсуждаемое исследование, возглавляемое Ю.Г. Леоновым, представляет собой весьма важное теоретическое и методологическое обобщение, полученное на основе изучения тектонических напряжений по геологическим данным в верхних частях земной коры для значительной территории, включающей в себя новейшие орогенные структуры как Кавказа, так и Скифской плиты и южного края Русской плиты. В работе продемонстрированы возможности коррекции геодинамических построений с помощью тектонофизических исследований, необходимость комплексирования как методов изучения напряженного состояния земной коры, так и всех типов имеющихся на сегодняшний день геолого-геофизических и сейсмологических данных. В исследовании четко сформулированы проблемы интерпретации полученных результатов стресс-мониторинга кайнозойских деформаций Северного Причерноморья, особенности исходного материала, лежащего в основе продольно-волнового механизма деформирования литосферных плит. В определенном смысле данное исследование можно считать развитием программы тектонофизических исследований, сформулированной в свое время М.В. Гзовским, но на другом витке развития тектонофизических исследований геологическими методами.

\section{5. ИЗУЧЕНИЕ ПАЛЕОТЕКТОНИЧЕСКИХ НАПРЯЖЕНИЙ ПО ОПЕРЯЮЩИМ РАЗРЫВАМ В ЗОНЕ ДИНАМИЧЕСКОГО ВЛИЯНИЯ СДВИГОВ}

Предложенный автором структурно-геоморфологический (СГ) метод реконструкции сдвиговых напряжений [Sim, 1991; Sim, Sergeev, 1996] основан на закономерной ориентации оперяющих («опережающих» [Seminsky, 1986]) разрывов в зонах динамического влияния сдвигов. Полевые и экспериментальные данные о взаимной ориентировке триады разноориентированных разрывов между собой и относительно плоскости сдвига были обобщены М.В. Гзовским [Gzovsky, 1975]. Позже углубленный анализ внутренней структуры зон сдвигов был сделан в работах [Seminsky, 2003, 2009], с выделением трех примерно перпендикулярных систем разрывов.

СГ метод дал возможность впервые охарактеризовать неотектонические напряжения платформ севера Европы и Азии (Западно-Европейская, Тимано-Печорская, Скифская, восточная часть Балтийского щита), включая складчатые структуры Урала, Пай-Хоя, Тимана, Карпат, Кавказа (рис. 8) [Sim et al., 1999; Sim, 2000]. На Восточно-Европейской платформе на ключевых участках (Мезенская синеклиза, Тиман, Балтийский щит) результаты реконструкции сдвиговых тектонических напряжений платформ, изложенные в работе [Sim et al., 2008], были подтверждены исследованиями тектонических напряжений кинематическим методом, а в пределах Западно-Сибирской плиты результатами сейсморазведки 3D [Gogonenkov et al., 2007]. В результате изучения напряженного состояния Северной Евразии установлена область влияния на плиты процессов спрединга в Северной Атлантике и Арктике. Граница между разными типами напряженного состояния на платформах проходит примерно вдоль границы Фенноскандинавского щита с Русской плитой, по западному краю палеозойской Белорусской антеклизы и обусловлена глубинным строением северной части Европы [Sim, 2000] (рис. 9). На Русской плите субмеридиональное сжатие, обусловленное тектогенезом в Арктике, сливается с влиянием процессов орогенеза на Кавказе. Согласно работе [Leonov et al., 2001], вероятность распространения влияния перемещения Аравийской плиты на неотектонические напряжения Русской плиты ограничена, поэтому не исключено, что в центральных частях Русской плиты заметный вклад вносят ротационные силы. На сегодняшний день, на наш взгляд, нет достаточных данных для решения этого вопроса.

\section{6. ТЕКТОНИЧЕСКИЕ НАПРЯЖЕНИЯ В РЕШЕНИИ ПРАКТИЧЕСКИХ ЗАДАЧ}

Неоценимая роль в решении практических задач принадлежит тектонофизическим исследованиям по- 

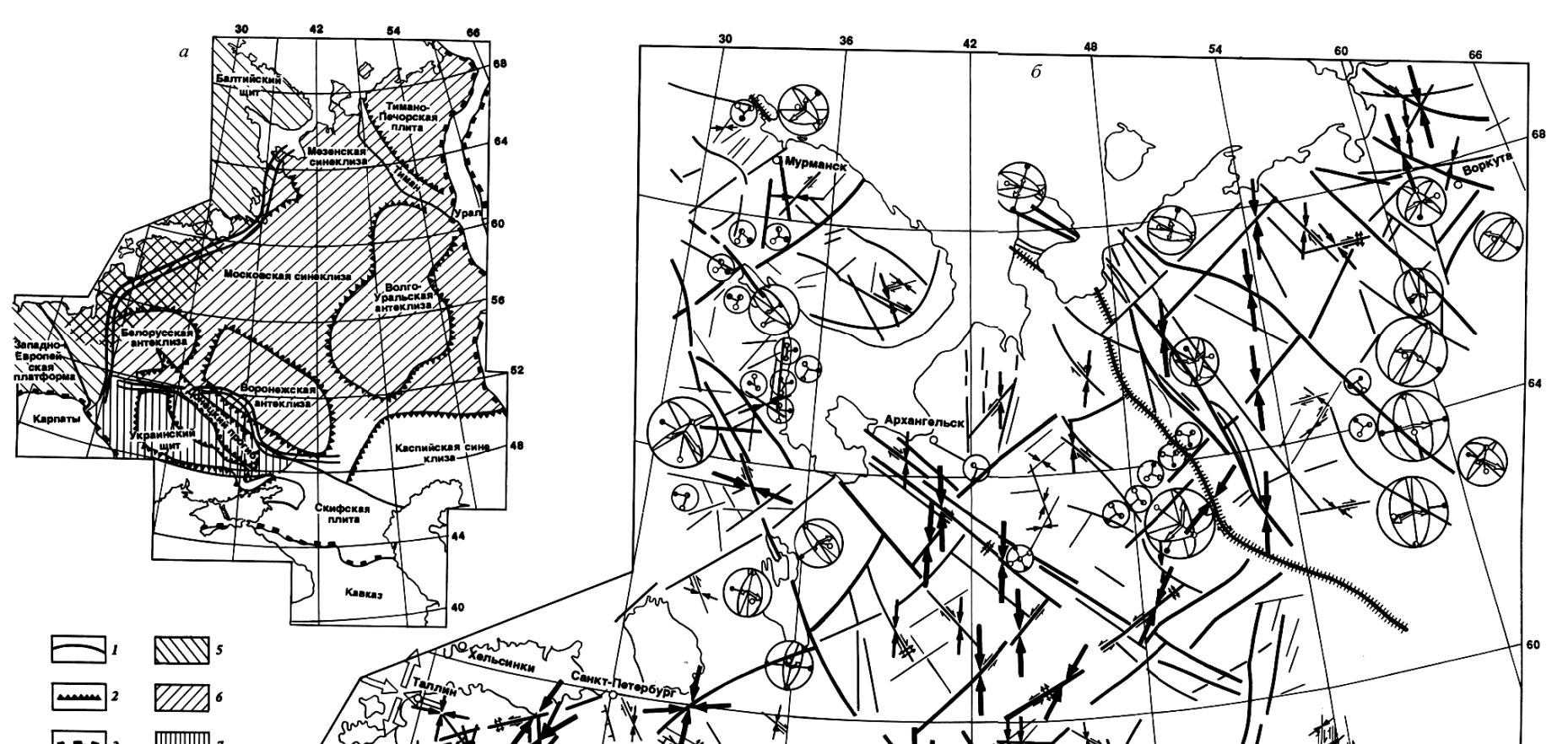

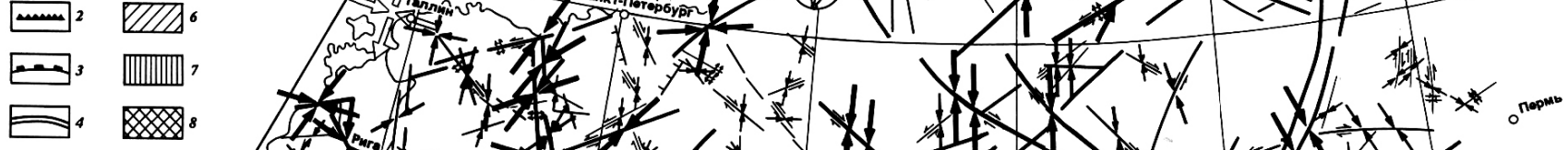
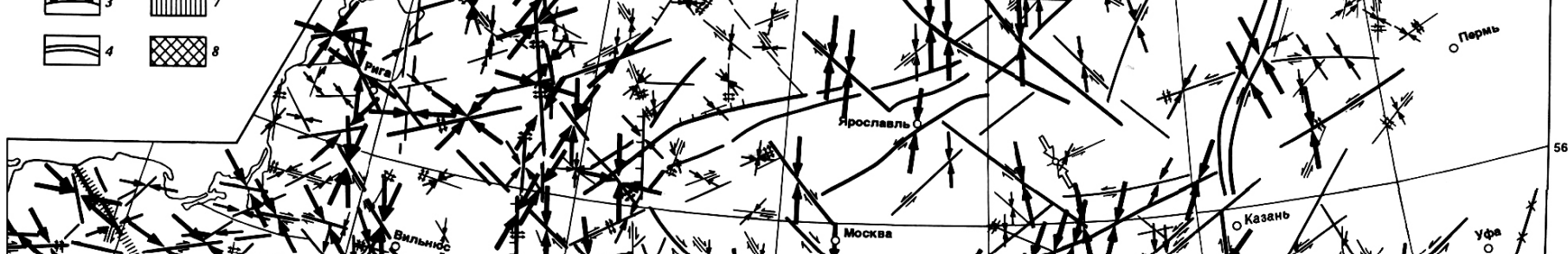
-

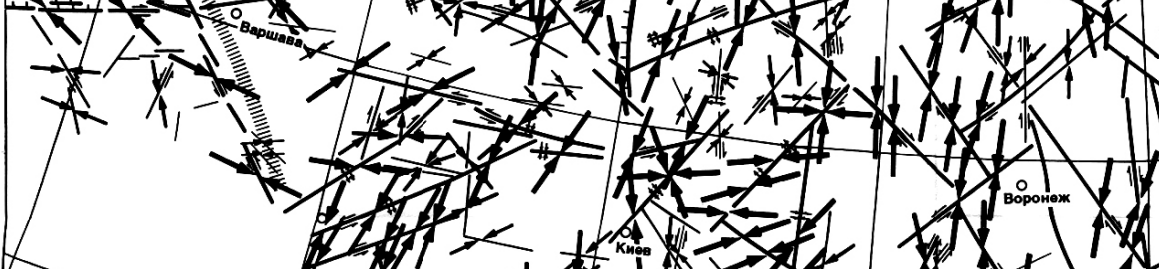

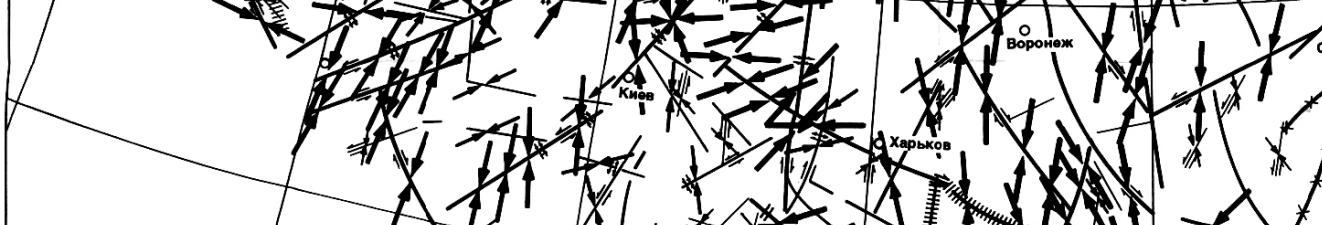

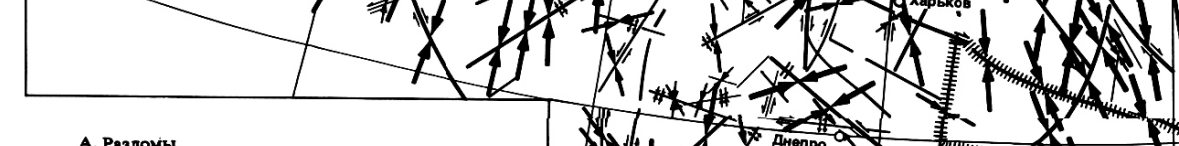

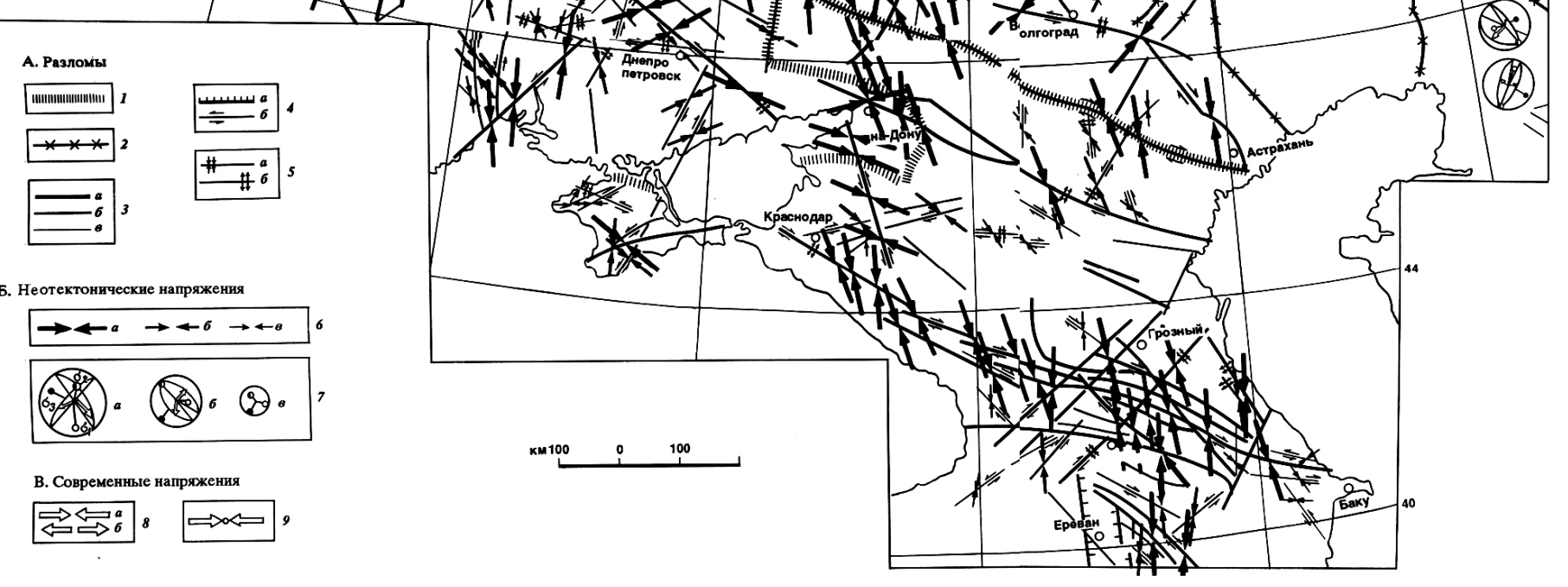


Рис. 8. Карта полей неотектонических напряжений Восточно-Европейской платформы и структур обрамления.

А. Разломы: 1 - зоны глубинных разломов, ограничивающих Восточно-Европейскую платформу; 2 - крупнейшие разломы фундамента с невыясненной неотектонической активизацией; 3 - неотектонические разломы ( $a$ - I, , 6 - II, в - III и более мелких рангов); 4 - кинематические типы разломов ( $a$ - сбросы, $\sigma$ - сдвиги); 5 - разломы, формирующиеся в обстановке сжатия $(a)$ и растяжения (б). Б. Неотектонические напряжения: 6 - оси сжатия в горизонтальной плоскости, установленные структурно-геоморфологическим методом $(a-\mathrm{I}, 6$ II, в - III и более мелких рангов); 7 - общие поля напряжений, восстановленные по векторам перемещений на зеркалах скольжения. Оси главных нормальных напряжений: растяжения $-\sigma_{1}$, промежуточная $-\sigma_{2}$, сжатия $-\sigma_{3} ; a-\mathrm{I}, \sigma-\mathrm{II}, \boldsymbol{8}-\mathrm{III}$ и более мелких рангов; на стереограммах показаны плоскости действия $\tau_{\max }$, стрелка на плоскости - направление перемещения в лежачем крыле (верхняя полусфера, сетка Вульфа). В. Современные напряжения: 8 - по механизмам в очагах землетрясений: оси сжатия (a) и растяжения (б); 9 - горизонтальное сжатие по данным инструментальных измерений. На врезке - схема районирования ВЕП и структур обрамления по типу неотектонических напряжений: 1 - зоны глубинных разломов; 2-4 - границы: 2 - крупнейших структур фундамента ВЕП, 3 - орогенных структур обрамления, 4 - областей с разным типом неотектонических напряжений; 5-8 - области с разными типами неотектонических напряжений: 5 - с субширотным и ЗСЗ сжатием, 6 - субмеридиональным сжатием, 7 - с неустойчивой ориентацией сжатия, 8 - с обстановкой растяжения [Sim, 2000].

Fig. 8. Map of neotectonic stress fields of the East European platform and frame structures.

A. Faults: 1 - zones of deep faults bordering the East European platform; 2 - major basement faults of unknown neotectonic activation; 3 - neotectonic faults ( $a$ - I, $\sigma$ - II, $\boldsymbol{B}$ - III and smaller ranks); 4 - kinematic types of faults ( $a$ - normal faults, $\sigma$ - shear faults); 5 - faults formed under conditions of compression (a) and extension (б). Б. Neotectonic stresses: 6 - compression axes in the horizontal plane, according to structural geomorphology ( $a$ - I, $\sigma$ - II, 8 - III and smaller ranks); 7 - general stress fields reconstructed from displacement vectors recorded from slikensides. Principal normal stress axes: extension $-\sigma_{1}$, intermediate $-\sigma_{2}$, compression $-\sigma_{3} ; a-\mathrm{I}, \sigma-\mathrm{II}, \boldsymbol{\beta}-\mathrm{III}$ and smaller ranks; on the stereograms there is an action plan $\tau_{\max }$, arrow on surface - displacement direction in the lying wall (upper hemisphere, Wulff net). B. Recent stresses: 8 - from earthquake focal mechanisms: axes of compression ( $a$ ) and extension (б); 9 - horizontal compression from instrumental measurement data. Insert: (a) - zonation of the East-European platform and frame structures by neotectonic stress types: 1 - zones of deep faults; 2-4 - boundaries: 2 - the largest basement structures of the East-European platform, 3 - orogenic frame structures, 4 - areas differing in neotectonic stress type; 5-8 - areas with different types of neotectonic stresses: 5 - sublatitudinal and WSW compression, 6 - submeridional compression, 7 - compression of unstable orientation, 8 - extension [Sim, 2000].

левыми методами, способствующим прогнозу условий локализации месторождений полезных ископаемых, оценке устойчивости горных выработок и крупных гражданских сооружений при проектировании водохранилищ, АЭС, выделению возможных сейсмоопасных зон и т.д. К таким работам относится изучение тектонических напряжений угольных месторождений Донбасса [Korchemagin, Ryaboshtan, 1987], урановых месторождений Забайкалья [Petrov et al., 2010], золоторудных месторождений Верхоянья [Zadorozhny, 2002], месторождений платины в Корякии [Vasiliev et al., 1999], алмазоносных трубок Якутии [Gladkov et al., 2008], месторождений пьезосырья на Приполярном Урале [Sim, 2000; Sim et al., 2005], рудных объектов Тянь-Шаня [Fatkhulaev, Umurzakov, 2009]. В большинстве работ, посвященных тектонофизическому изучению мест локализации полезных ископаемых, показана доминирующая роль разломов в формировании рудных месторождений [Sim et al., 1987; Gladkov et al., 2008].

В проблеме прогноза мест локализации гидротермально-метасоматических месторождений полезных ископаемых важную роль играет особое напряженное состояние, названное вариацией вида напряженного состояния (ВBHC) [Sim, 1982]. Оно характеризуется постоянством ориентаций главных нормальных напряжений и максимальной дисперсией параметра $\mu \sigma$ от -1 до +1 с подчиненным количеством промежуточных значений. Таким образом, определенные объемы горных пород деформируются в разном режиме попеременно - то при одноосном сжатии, то при одноосном растяжении без изменения ориентировки осей главных нормальных напряжений. Принадлежность борозд скольжения единому локальному стресс-состоянию подтверждается нахождением в этом же объеме до 20-30 \% борозд скольжения, не противоречащих ориентировке оси сжатия и растяжения, но сформированных при $\mu \sigma \neq|1|$. Такой тип деформирования характерен для мест пересечения разрывов 2, 3-го порядка и, возможно, обусловлен попеременными перемещениями по отдельным разрывам. На Приполярном Урале к участкам с ВВНС приурочены гнезда горного хрусталя. В.А. Корчемагиным показано, что с такими участками связаны выбросы газа в шахтах Донбасса, а также прогнозировано наличие термальных вод во Вьетнаме. Не менее важная роль принадлежит максимальным значениям величин приращения вертикальной компоненты деформаций, названной «вертикальным «разуплотнением» горных пород» (ВРГП - сокращение Л.С.) [Vasiliev, Mostryukov, 2000]. В синрудный этап деформирования в платиноносном массиве дунитгарцбургитов Ватыно-Вывенской сутуры Корякского нагорья были выделены блоки со сдвиговыми и взбросовыми тектоническими напряжениями. Блоков со взбросовыми полями оказалось существенно меньше, чем со сдвиговыми. В блоках со сдвиговым механизмом деформирования отмечен процесс взаимного вертикального уплотнения-разуплотнения пород, для блоков со взбросовым типом напряжений характерен процесс некомпенсированного разуплотнения. Совместное исследование характеристик ВРГП и проявления металла показало, что последние концентрируются 


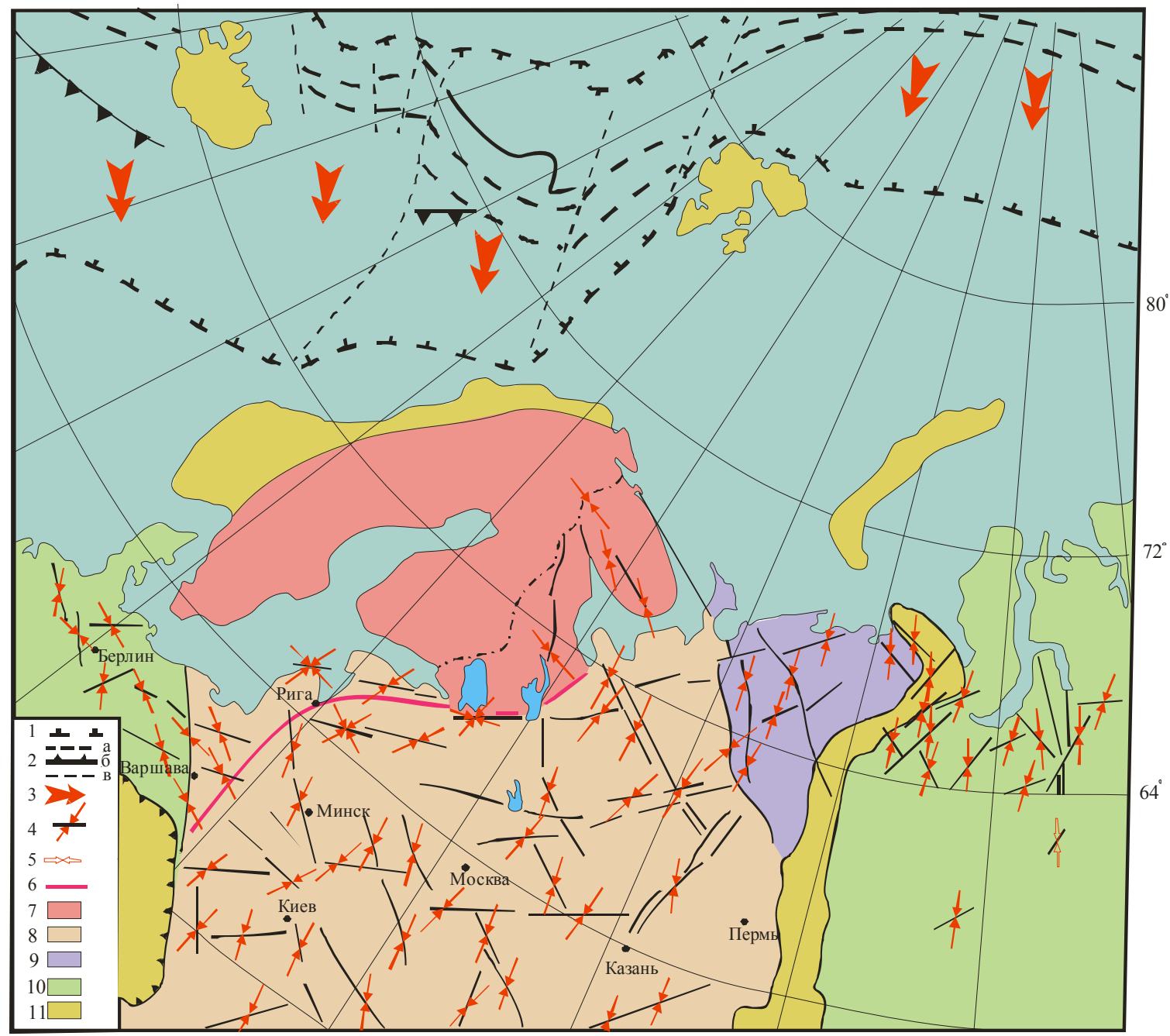

Рис. 9. Неотектонические напряжения севера Евразии.

1 - контуры шельфа; 2 - океанические структуры: а - центральные, б - периферические части срединно-океанических хребтов, в трансформные разломы; 3 - ориентация сжатия, обусловленная процессами спрединга; 4-5 - ориентировки региональных осей сжатия в горизонтальной плоскости: 4 - восстановленные кинематическим и СГ методами, 5 - по сейсмике 3Д [Gogonenkov et al., 2007]; 6 - граница между западным (северо-западные и широтные) и восточным (субмеридиональные) типами ориентировок осей сжатия; 7-11 - континентальные тектонические структуры: 7 - Фенноскандинавский (Балтийский) щит, 8 - Русская плита, 9 - Западно-Европейская и Западно-Сибирская плиты, 10 - Тиманиды и Тимано-Печорская плита, 11 - разновозрастные складчатые комплексы.

Fig. 9. Neotectonic stresses of the Northern Eurasia.

Legend: 1 - shelf contours; 2 - oceanic structures: a - central, 6 - peripheral parts of mid-ocean ridges, B - transform faults; 3 - orientation of compression associated with spreading; 4-5 - orientations of regional compression axes in the horizontal plane: 4 - from kinematic and structural geological data, 5 - from 3D seismical data [Gogonenkov et al., 2007]; 6 - boundary between areas with the western (NW and latitudinal) and eastern (submeridional) orientations of compression axes; 7-11 - continental tectonic structures: 7 - Fennoscandian (Baltic) shield, 8 - Russian plate, 9 - West-European and West-Siberian plates, 10 - Timanides and Timan-Pechora plate, 11 - fold complexes of various ages.

вдоль границ с высокоградиентными зонами ВРГП. Эти границы, являясь пограничными зонами флюидной проницаемости пород на синрудном этапе, свидетельствуют о проявлении деформационного фактора структурного контроля пространственного размещения геохимических барьеров и, соответственно, концентрации металлов. «В целом результаты исследования обосновывают высокую перспективность применения тектонофизических методов анализа к изучению закономерностей размещения флюидного оруденения в массивах горных пород» [Vasiliev, Mostryukov, 2000, c. 294]. ВВНС и ВРГП устанавливаются только при реконструкции тектонических напряжений кинематическим методом.

Разномасштабные исследования неотектонических напряжений платформ СГ методом, проведенные автором, показали высокую значимость секторов локального растяжения и сжатия, формирующихся на местах пересечения разнонаправленных сдвигов при решении прикладных задач. Так, в условиях субмеридионально- 
го сжатия и субширотного растяжения (Русская плита, Западная Сибирь), при пересечении правых сдвигов северо-западного простирания с левыми - северо-восточного простирания, секторы, открытые на запад и восток, характеризуются обстановкой локального растяжения, а секторы, открытые на север и юг, - локального сжатия. В секторах растяжения фиксируется аномальное развитие карстовых процессов из-за повышенной проницаемости гипсоносных пород (г. Дзержинск) [Sim, 2000]; к ним приурочены участки с постоянными нарушениями рабочего состояния железнодорожных путей (Смоленская обл.) и газопроводов (Тверская обл.); в таких секторах отмечается высокий начальный дебит скважин на месторождениях углеводородов (Б. Салым, Ай-Пим, Западная Сибирь).

Развитие науки и практики требует оценки величины тектонических напряжений, восстановленных по геологическим данным. На сегодняшний день к решению этой задачи вплотную приблизились сотрудники лаборатории тектонофизики ИФЗ РАН [Rebetsky et al., 2011], что в перспективе выведет изучение палеотектонических напряжений по геологическим индикаторам на принципиально новый уровень.

\section{7. Выводы}

Почти за 60 лет со времени разработки полевого метода реконструкции тектонических напряжений М.В. Гзовским тектонофизические исследования по геологическим индикаторам достигли определенных успехов в своем развитии, а именно:

- разработаны статистический, кинематический, структурно-парагенетический, катакластический, стресс-мониторинговый, структурно-геоморфологический и другие методы, позволившие провести региональное изучение напряженного состояния для практически всей территории России и стран СНГ;

- исследованы механизмы формирования тектонических структур различного масштаба;

- на основании переиндексации осей главных нормальных напряжений в процессе непрерывного деформирования, установленной эмпирически, разработана гипотеза закономерной смены фаз в едином цикле; гипотеза требует дальнейшего обоснования, тем не менее она весьма перспективна для развития тектонофизических исследований;

- показано, что в геологической среде, прошедшей неоднократное деформирование, при реализации перемещений по ослабленным поверхностям картируются векторы перемещений на плоскостях, отклоняющихся от теоретических и модельных представлений за счет неоднородности свойств среды;

- разработаны тектонофизические критерии прогноза мест локализации полезных ископаемых гидротермального и гидротермально-метасоматического генезиса, а также прогноза участков с развитием неблагоприятных современных процессов.

\section{8. ЛИТЕРАТУРА}

Angelier J., 1975. Sur l'analyse de measures recueilles dans des sites failles: l'utilite d'une confrontation entre les methods dynamiques et cinematiquues. Bulletin de la Societe Geologique de France 281, 1805-1808.

Angelier J., Gushtchenko O.I., Saintot A., Ilyin A., Rebetsky Y.L., Vassiliev N., Malutin S., 1994. Relations entre champs de contraintes et de'formations le long d'une chaine compressive-de'crochante: crime'e et Caucase (Russie et Ukraine). Comptes Rendus de l'Académie des Sciences - Series II (319), 341-348.

Bankwitz P., 2000. Interpretation of destruction traces on surfaces of fractures in view of reconstruction of recent and palaeostresses. In: M.V. Gzovsky and development of tectonophysics. Nauka, Moscow, p. 266-281 (in Russian) [Банквитц П. Интерпретация следов разрушения на поверхностях трещин в связи с реконструкцией современных и палеонапряжений // М.В. Гзовский и развитие тектонофизики. М.: Наука, 2000. С. 266-281].

Bankwitz P., Bankwitz E., 1984. Die Symmetrievon Klueftoberflaechen und ihre Nutzung fuer eine Palaeospannungsanalyse. Zeitschrift für Geologische Wissenschaften 12, 305-334.

Fatkhulaev Sh.D., Umurzakov R.A., 2009. Tectonophysical features in studies of ore deposits varying in scale and specific regional features of manifestation of recent stress fields in regions of the Tien Shan from geological and structural data. In: Tectonophysics and current issues of the Earth sciences. Proceedings of the All-Russia Conference. IPE RAS, Moscow, p. 415-420 (in Russian) [Фатхулаев Ш.Д., Умурзаков Р.А. Тектонофизические особенности изучения разномасштабных рудных объектов и региональные особенности проявления новейших полей напряжений отдельных областей Тянь-Шаня по геолого-структурным данным // Тектонофизика и актуальные вопросы наук о Земле: Материалы Всероссийской конференции. М.: ИФЗ РАН, 2009. С. 415-420].

Gintov O.B., Isai V.M., 1984a. Some regularities of faulting and the method of morpho-kinematic analysis of shear faults. Geofizicheskiy Zhurnal 6 (3), 3-10 (in Russian) [Гинтов О.Б., Исай В.М. Некоторые закономерности разломообразования и методика морфокинематического анализа сколовых разломов // Геофизический журнал. 1984а. Т. 6. № 3. С. 3-10].

Gintov O.B., Isai V.M., 1984b. Some regularities of faulting and the method of morpho-kinematic analysis of shear faults. Geofizicheskiy Zhurnal 6 (4), 3-14 (in Russian) [Гинтов О.Б., Исай В.М. Некоторые закономерности разломообразования и методика морфокинематического анализа сколовых разломов // Геофизический журнал. 1984b. Т. 6. № 4. С. 3-14]. 
Gintov O.B., Murovskaya A.V., 2000a. The problem of crustal dynamics of the Crimean Peninsula in the Meso-Cenozoic (tectonophysical aspect). Geofizicheskiy Zhurnal 22 (2), 39-60 (in Russian) [Гинтов О.Б., Муровская А.В. Проблемы динамики земной коры Крымского полуострова в мезо-кайнозое (тектонофизический аспект) // Геофизический журнал. 2000а. Т. 22. № 2. С. 39-60].

Gintov O.B., Murovskaya A.V., 2000b. The problem of crustal dynamics of the Crimean Peninsula in the Meso-Cenozoic (tectonophysical aspect). Geofizicheskiy Zhurnal 22 (3), 39-49 (in Russian) [Гинтов О.Б., Муровская А.В. Проблемы динамики земной коры Крымского полуострова в мезо-кайнозое (тектонофизический аспект) // Геофизический журнал. 2000b. Т. 22. № 3. С. 36-49].

Gladkov A.V., Bornyakov S.A., Manakov A.B., Matrosov V.A., 2008. Tectonophysical Research in Diamond Prospecting. Moscow, Nauchny Mir, 182 p. (in Russian) [Гладков А.С., Борняков С.А., Манаков А.Б., Матросов В.А. Тектонофизические исследования при алмазоносных поисковых работах. М.: Научный мир, 2008. 182 с.].

Gogonenkov G.N., Kashik A.S., Timurziev A.I., 2007. Horizontal shifts of the basement in West Siberia. Geologiya nefti $i$ gaza 3, 3-10 (in Russian) [Гогоненков Г.Н., Кашик А.С., Тимурзиев А.И. Горизонтальные сдвиги фундамента Западной Сибири // Геология нефти и газа. 2007. № 3. С. 3-10].

Gusev G.S., 1979. Folded Structures and Faults of the Verkhoyansk-Kolyma System of Mesozoids. Nauka, Moscow. 208 p. (in Russian) [Гусев Г.С. Складчатые структуры и разломы Верхояно-Колымской системы мезозоид. М.: Наука, 1979. 208 c.].

Gushchenko O.I., 1973. Analysis of tectonic shear orientations and their tectonophysical interpretation in reconstruction of palaeostresses. Doklady AN SSSR 210 (2), 331-334 (in Russian) [Гущенко О.И. Анализ ориентировок сколовых тектонических смещений и их тектонофизическая интерпретация при реконструкции палеонапряжений // Доклады АН CССР. 1973. T. 210. № 2. С. 331-334].

Gushchenko O.I., 1979. The method of kinematic analysis of destruction structures in reconstruction of tectonic stress fields. In: Fields of stress and strain in the lithosphere. Nauka, Moscow, p. 7-25 (in Russian) [Гущенко О.И. Метод кинематического анализа структур разрушения при реконструкции полей тектонических напряжений // Поля напряжений и деформаций в литосфере. М.: Наука, 1979. С. 7-25].

Gushchenko O.I., 1999. The kinematic principle of relative chronology of palaeostresses. In: Theoretical and regional problems of geodynamics. Proceedings of Geological Institute, RAS. Nauka, Moscow, Issue 515, p. $108-125$ (in Russian) [Гущенко О.И. Кинематический принцип относительной хронологии палеонапряжений // Теоретические и региональные проблемы геодинамики. Труды ГИН РАН. М.: Наука, 1999. Вып. 515. С. 108-125].

Gushchenko O.I., Gushchenko N.Yu., Mostryukov A.O., Kuznetsov V.A., Sergeev A.A., Petrov V.A., Ilyin A.V., Rastsvetaev L.M., Tveritinova T.Yu., Sim L.A., Korchemagin D.V., Vasiliev N.Yu., Dudnik V.A., Korchemagin V.A., 2001. Tectonic stress monitoring and stress fields of the Near-Black Sea region. Proceedings of the Donetsk National Technical University. Mining Geology Series 32, p. 104-117 (in Russian) [Гущенко О.И., Гущенко Н.Ю., Мострюков А.О., Кузнецов В.А., Сергеев А.А., Петров В.А., Ильин А.В., Расцветаев Л.М., Тверитинова Т.Ю., Сим Л.А., Корчемагин Д.В., Васильев Н.Ю., Дудник В.А., Корчемагин В.А. Тектонический стресс-мониторинг и поля напряжений Причерноморского региона // Наукові праці Донецького національного технічного університету. Серія: Гірничо-геологічна. 2001. Випуск 32. С. 104-117].

Gzovsky M.V., 1954. Tectonic stress fields. Izvestiya AN SSSR. Seriya 5. Geofizika 5, 390-410 (in Russian) [Гзовский M.В. Тектонические поля напряжений // Известия АН СССР. Серия. 5. Геофизика. 1954. № 5. С. 390-410].

Gzovsky M.V., 1959. Main Issues of Tectonophysics and Tectonics of the Baydzhansayskoe Anticlinorium. Publishing House of the USSR Academy of Sciences, Moscow. Vol. I-II, 256 p. (in Russian) [Гзовский М.В. Основные вопросы тектонофизики и тектоника Байджансайского антиклинория. М.: Издательство АН СССР, 1959. Ч. I-II. 256 с.].

Gzovsky M.V., 1963. Main Issues of Tectonophysics and Tectonics of the Baydzhansayskoe Anticlinorium. Publishing House of the USSR Academy of Sciences, Moscow. Vol. III-IV, 544 p. (in Russian) [Гзовский М.B. Основные вопросы тектонофизики и тектоника Байджансайского антиклинория. М.: Издательство АН СССР, 1963. Ч. III-IV. 544 с.].

Gzovsky M.V., 1975. Fundamentals of Tectonophysics. Nauka, Moscow, 536 p. (in Russian) [Гзовский М.В. Основы тектонофизики. М.: Наука, 1975. 536 с.].

Kopp M.P., Adzhamyan Zh., Il'yas K., Fakiani F., Khafez A., 1999. Mechanism of formation of the El Ghab Wrench graben (Syria) and the Levant Transform Fault propagation. Geotectonics 33 (5), 408-422.

Kopp M.L.,Tveritinova T.Yu., 1999. Kinematics of the Zhigulevsky fault. Bulletin of Moscow Society of Naturalists. Department of Geology 74 (5), 18-29 (in Russian) [Konn М.Л., Тверитинова Т.Ю. Кинематика Жигулевского разлома // Бюллетень Московского общества испытателей природы. Отдел геологический. 1999. Т. 74. Вып. 5. С. 18-29].

Korchemagin V.A., 1984. The Geological Structure and the Stress Field in Relation to Evolution of Endogenous Regimes in Donbass. Synopsis of $\mathrm{PhD}$ Thesis (Candidate degree in geology and mineralogy). IEP, the USSR Academy of Sciences, Moscow, 24 p. (in Russian) [Корчемагин B.A. Геологическая структура и поля напряжений в связи с эволюцией эндогенных режимов Донбасса: Автореф. дис. ... докт. геол.-мин. наук. М.: ИФЗ АН СССР, 1984. 24 с.].

Korchemagin V.A., Abakumov V.V., Danaev A.I., Korchemagin D.V., Dudnik V.A., 2000. Structural and tectonophysical characteristics of the eastern part of Alai and Trans-Alay ridges. In: M.V. Gzovsky and development of tectonophysics. Nauka, Moscow, p. 295-310 (in Russian) [Корчемагин В.А., Абакумов В.В., Данаев А.И., Корчемагин Д.В., Дудник B.A. Структурно-тектонофизическая характеристика восточной части Алайского и Заалайского хребтов // М.В. Гзовский и развитие тектонофизики. М.: Наука, 2000. С. 295-310]. 
Korchemagin V.A., Emets V.S., 1982. On the method of identification and reconstruction of superimposed tectonic stress fields. Doklady AN SSSR 1 (263), 163-168 (in Russian) [Корчемагин В.А., Емец В.С. К методике выделения и реконструкции наложенных тектонических полей напряжений // Доклады АН СССР. 1982. Т. 263. № 1. С. 163-168].

Korchemagin V.A., Ryaboshtan Yu.S., 1987. Tectonics and stress fields in Donbass. In: Stress and strain fields of the Earth's crust. Nauka, Moscow, p. 164-170 (in Russian) [Корчемагин B.А., Рябоштан Ю.С. Тектоника и поля напряжений Донбасса // Поля напряжений и деформаций в земной коре. М.: Наука, 1987. С. 164-170].

Leonov Yu.G., Gushchenko O.I., Kopp M.L., Rastsvetaev L.M., 2001. Relationship between the Late Cenozoic stresses and deformations in the Caucasian sector of the Alpine belt and its Northern foreland. Geotectonics 35 (1), 30-50.

Lunina O.V., Gladkov A.S., 2008. Active faults and crustal stress in the northeastern flank of the Baikal rift system. Russian Geology and Geophysics 49 (2), 113-123. http://dx.doi.org/10.1016/j.rgg.2008.01.004.

Marinin A.V., Saintot A., 2008. Comparison of results of palaeostress studies in the North-Western Caucasus by different tectonophysical methods. In: Problems of tectonophysics. The 40th anniversary of foundation of Laboratory of Tectonophysics, IPE RAS, by M.V. Gzovsky. IPE RAS, Moscow, p. 225-243 (in Russian) [Маринин А.В., Сайнто А. Сравнение результатов исследований палеонапряжений Северо-Западного Кавказа различными тектонофизическими методами // Проблемы тектонофизики. К 40-летию создания М.В. Гзовским лаборатории тектонофизики в ИФЗ РАН. М.: ИФЗ РАН, 2008. С. 225-243].

Marinin A.V., Saintot A., 2012. Comparison of methods to reconstruct paleostress regimes in the NW-Greater Caucasus foldand-thrust belt. Comptes Rendus Geoscience 344 (3), 181-190. http://dx.doi.org/10.1016/j.crte.2012.01.004.

Markov G.A., 1977. Tectonic Stress and Confining Pressure in Mines at the Khibiny Massif. Nauka, Leningrad, 213 p. (in Russian) [Марков Г.А. Тектонические напряжения и горное давление в рудниках Хибинского массива. Л.: Наука, 1977. 213 c.].

Nikolaev P.N., 1977. Methods of statistical analysis of fractures and reconstruction of tectonic stresses. Izvestiya VUZov, Geologiya i Razvedka 12, 103-115 (in Russian) [Николаев П.Н. Методика статистического анализа трещин и реконструкция тектонических напряжений // Известия ВУЗов, Геология и Разведка. 1977. № 12. С. 103-115].

Nikolaev P.N., 1992. The Method of Tectono-Dynamic Analysis. Nedra, Moscow, 263 p. (in Russian) [Николаев П.Н. Методика тектоно-динамического анализа. М.: Недра, 1992. 263 с.].

Pack A.V., 1947. Some issues of fracture tectonics in mining geology. Sovetskaya Geologiya 20, 196 (in Russian) [Пэк А.В. Некоторые вопросы трещинной тектоники в рудничной геологии // Советская геология. 1947. № 20. С. 196].

Parfeevets A.V., Sankov S.V., 2006. The State of Crustal Stresses and Geodynamics of the South-Western Part of the Baikal Rift System. Publishing House of SB RAS, GEO Branch, Novosibirsk, 151 p. (in Russian) [Парфеевец А.В., Саньков В.A. Напряженное состояние земной коры и геодинамика юго-западной части Байкальской рифтовой системы. Новосибирск: Издательство СО РАН. Филиал «ГЕО», 2006. 151 с.].

Petrov V.A., Mostryukov A.O., Vasiliev N.Y., 2008. Structure of recent field of stresses of mezozoic-cenozoic cycle of deformations of the Baikal rift zone. Geophysical research 9 (3), 39-61.

Petrov V.A., Sim L.A., Nasimov R.M., Shchukin S.I., 2010. Fault tectonics, neotectonic stresses, and hidden uranium mineralization in the area adjacent to the Strel'tsovka Caldera. Geology of Ore Deposits 52 (4), 279-288. http://dx.doi.org/ 10.1134/S1075701510040033.

Rastsvetaev L.M., 1982. Structural drawings of fractures and their geomechanical interpretation. Doklady AN SSSR 267 (4), 904-909 (in Russian) [Расцветаев Л.M. Структурные рисунки трещиноватости и их геомеханическая интерпретация // Доклады АН СССР. 1982. Т. 267. № 4. С. 904-909].

Rastsvetaev L.M., 1987. Tectono-dynamic conditions of formation of the Alpine structure of the Greater Caucasus. In: Geological and mineral resources of the Greater Caucasus. Nauka, Moscow, p. 69-96 (in Russian) [Расцветаев Л.М. Тектодинамические условия формирования альпийской структуры Большого Кавказа // Геологические и полезные ископаемые Большого Кавказа. М.: Наука, 1987. С. 69-96].

Rebetsky Yu.L., 1997. Reconstruction of tectonic stresses and seismotectonic strains: Methodical fundamentals, current stress field of Southeastern Asia and Oceania. Doklady Earth Sciences 354 (4), 560-563.

Rebetsky Yu.L., Sim L.A., Kozyrev A.A., Rybin V.V., Zhirov D.V., 2011. The first estimates of stresses from geological data. In: The Current State-of-the-Art in Earth Science. International Conference dedicated to the memory of V.E. Khain. Moscow State University, Moscow, p. 1553-1555. Available from: http://khain2011.web.ru (last accessed 1.07.2013) (in Russian) [Ребецкий Ю.Л., Сим Л.А., Козырев А.А., Рыбин В.В., Жиров Д.В. Первые оценки величин напряжений по геологическим данным // Современное состояние наук о Земле. Международная конференция, посвященная памяти В.Е. Хаина. М.: МГУ, 2011. С. 1553-1555. Available from: http://khain2011.web.ru (last accessed 1.07.2013)].

Saintot A., Angelier J., 2002. Tectonic paleostress fields and structural evolution of the NW-Caucasus fold-and-thrust belt from Late Cretaceous to Quaternary. Tectonophysics 357 (1-4), 1-31. http://dx.doi.org/10.1016/S0040-1951(02)00360-8.

Seminsky K.Zh., 1986. Analysis of distribution of leading fractures during formation of large faults. Geologiya i Geofizika 10, 9-18 (in Russian) [Семинский К.Ж. Анализ распределения опережающих разрывов при формировании крупных дизъюнктивов // Геология и геофизика. 1986. № 10. С. 9-18].

Seminsky K.Zh., 2003. The Internal Structure of Continental Fault Zones. Tectonophysical Aspect. Publishing House of SB RAS, GEO Branch, Novosibirsk, 242 p. (in Russian) [Семинский К.Ж. Внутренняя структура континентальных раз- 
ломных зон. Тектонофизический аспект. Новосибирск: Издательство СО РАН. Филиал «ГЕО», 2003. 242 с.].

Seminsky K.Zh., 2009. Tectonophysical analysis of the internal structure of fault zones. In: Modern tectonophysics. Methods and results. Material of the 1st Youth Workshop. IPE, Moscow, p. 258-276 (in Russian) [Семинский К.Ж. Тектонофизический анализ внутренней структуры разломных зон // Современная тектонофизика. Методы и результаты. Материалы 1-й молодежной школы-семинара. М.: ИФЗ, 2009. С. 258-276].

Sherman S.I., Dneprovsky Yu.I., 1989. Stress Fields of the Earth's Crust and Geological and Structural Methods of Their Study. Siberian Branch, Nauka, Novosibirsk, 261 p. (in Russian) [Шерман С.И., Днепровский Ю.И. Поля напряжений земной коры и геолого-структурные методы их изучения. Новосибирск: Наука. Сибирское отделение, 1989. 261 c.].

Sim L.A., 1982. Change of the state of stresses as a sign of rock-crystal-bearing capacity (exemplified by Nether-Pole Urals). In: Experimental tectonics in solving problems of theoretical and practical geology. Abstracts of the First All-Union Symposium. Novosibirsk, p. 120-121 (in Russian) [Сим Л.А. Изменение вида напряженного состояния как признак хрусталеносности (на примере ПриполярногоУрала) // Экспериментальная тектоника в решении задач теоретической и практической геологии: Тезисы Первого Всесоюзного симпозиума. Новосибирск, 1982. С. 120-121].

Sim L.A., 1991. Studies of tectonic stress from geological indicators (methods, results, recommendations). Izvestia VUZov, Geologiya i Razvedka 10, 3-22 (in Russian) [Сим Л.А. Изучение тектонических напряжений по геологическим индикаторам (методы, результаты, рекомендации) // Известия ВУЗов, Геология и Разведка. 1991. № 10. С. 3-22].

Sim L.A., 2000. The impact of global tectogenesis on the most recent state of stresses of platforms in Europe. In: M.V. Gzovsky and development of tectonophysics. Nauka, Moscow, p. 326-350 (in Russian) [Сим Л.А. Влияние глобального тектогенеза на новейшее напряженное состояние платформ Европы // М.В. Гзовский и развитие тектонофизики. М.: Наука, 2000. С. 326-350].

Sim L.A., 2012. Some methodological aspects of tectonic stress reconstruction based on geological indicators. Comptes Rendus Geoscience 344 (3), 174-180. http://dx.doi.org/10.1016/j.crte.2011.11.003.

Sim L.A., Bryantseva G.V., Chekmarev K.V., 2008. On transformation of the structural plan of the northern part of the WestSiberian plate and the Polar Urals in the latest stage. In: Problems of tectonophysics. The 40th anniversary of foundation of Laboratory of Tectonophysics, IPE RAS, by M.V. Gzovsky. IPE RAS, Moscow, p. 301-318 (in Russian) [Cим Л.А., Брянцева Г.В., Чекмарев К.В. О перестройке структурного плана севера Западно-Сибирской плиты и Полярного Урала в новейший этап // Проблемы тектонофизики. К 40-летию создания М.В. Гзовским лаборатории тектонофизики в ИФЗ РАН. М.: ИФЗ РАН, 2008. С. 301-318].

Sim L.A., Korchemagin V., Frischbutter A., Bankwitz P., 1999. The neotectonic stress field pattern of the East European Platform. Zeitschrift für Geologische Wissenschaften 27 (3-4), 161-181.

Sim L.A., Sergeev A.A., 1996. Eine strukturell-geomorphologische Methode zur Analyse aktiver Bruche mit dem Ziel der bestimmung neotectonischer Spannungen in Tafelgebieten. Zeitschrift für Geologische Wissenschaften 20, 369-375.

Sim L.A., Vasiliev N.Yu., Korchemagin V.A., Emets V.S., 1987. Stress fields in fault zones and formation of structures of ore fields. In: Stress and strain fields of the Earth's Crust. Nauka, Moscow, p. 151-158 (in Russian) [Сим Л.А., Васильев Н.Ю., Корчемагин В.А., Емец В.С. Поля напряжений в зонах разломов и формирование структуры рудных полей // Поля напряжений и деформаций в земной коре. М.: Наука, 1987. С. 151-158].

Sim L.A., Yurchenko O.S., Sirotkin O.A., 2005. Tectonic stresses of the northern parts of the Urals. Geofizicheskiy Zhurnal 27 (1), 110-120 (in Russian) [Сим Л.А., Юрченко О.С., Сироткина О.А. Тектонические напряжения северных частей Урала // Геофизический журнал. 2005. Т. 27. № 1. С. 110-120].

Umurzakov R.A., 2009. Stress fields and mechanism of earthquake foci in mountainous areas of the Tien Shan from geological and structural data. In: Tectonophysics and current issues of the Earth sciences. Proceedings of the All-Russia Conference. IPE RAS, Moscow, p. 408-414 (in Russian) [Умурзаков Р.A. Поля напряжений и механизм формирования очагов землетрясений в некоторых горных областях Тянь-Шаня по геолого-структурным данным // Тектонофизика и актуальные вопросы наук о Земле: Материалы Всероссийской конференции. М.: ИФЗ РАН, 2009. C. 408-414].

Vasiliev N.Yu., Korchemagin V.A., Mostryukov A.N., Nikolskaya N.V., Sim L.A., 1999. Phases and stages of tectonic loading in evolution of the gabbro-pyroxenite-dunite massif (Vatyno-Vyvenskaya suture, Koryak highlands). In: Tectonics, geodynamics and processes of magmatism and metamorphism. Materials of the XXXII tectonic meeting. GEOS, Moscow, Vol. 1, p. 121-123 (in Russian) [Васильев Н.Ю., Корчемагин В.А., Мострюков А.Н., Никольская Н.В., Сим Л.А. Этапы и стадии тектонического нагружения в эволюционном развитии массива габбро-пироксенит-дунитовой формации (Ватыно-Вывенская сутура, Корякское нагорье) // Тектоника, геодинамика и процессы магматизма и метаморфизма: Материалы XXXII Тектонического совещания. М.: ГЕОС, 1999. Т. 1. С. 121-123].

Vasiliev N.Yu., Mostryukov A.O., 2000. Tectonophysical reconstruction of conditions of precious metals placement in dunites of the laminated massif. In: M.V. Gzovsky and development of tectonophysics. Nauka, Moscow, p. 281-295 (in Russian) [Васильев Н.Ю., Мострюков А.О. Тектонофизическая реконструкция условий размещения благородных металлов в дунитах расслоенного массива // М.В. Гзовский и развитие тектонофизики. М.: Наука, 2000. С. 281-295].

Vasiliev N.Yu., Mostryukov A.O., 2001. Regularities in development of deformation cycles in processes of tectogenesis. In: Tectonics of the Neogean: General and regional aspects. GEOS, Moscow, Vol. 1, p. 90-93 (in Russian) [Васильев Н.Ю., Мострюков А.О. Закономерности развития циклов деформации в процессах тектогенеза // Тектоника неогея: общие и региональные аспекты. М.: ГЕОС, 2001. Т. 1. С. 90-93]. 
Vasilyev N.J., Mostrjukov A., Sim L., 2002. Die Rolle der tektonischen Spannungen bei Entwicklung der Eldjutinsk-Granitoid Koerpers und seines Rahmens (Kaukasus) - Tectonophysikalische Rekonstruktion. Zeitschrift für Geologische Wissenschaften 30 (1-2), 131-144.

Yakovlev F.L., Sim L.A., 2007. On the relation between fields of tectonic stresses and strain (exemplified by the Vorontsovsky cover, North-Western Caucasus). In: Fundamental problems of geotectonics. Materials of the XI tectonic Meeting. GEOS, Moscow, p. 397-400 (in Russian) [Яковлев Ф.Л., Сим Л.А. О соотношении поля тектонических напряжений и поля деформаций (на примере Воронцовского покрова, Северо-Западный Кавказ) // Фундаментальные проблемы геотектоники: Материалы ХІ тектонического совещания. М.: ГЕОС, 2007. С. 397-400].

Zadorozhny D.N., 2002. Tectonophysical Criteria for Prediction of Mineralization of the Verkhoyanskaya Silver-Bearing Province. Synopsis of $\mathrm{PhD}$ Thesis (Candidate degree in geology and mineralogy). Moscow State University, Moscow, 24 p. (in Russian) [Задорожный Д.Н. Тектонофизические критерии прогноза оруденения Верхоянской сереброносной провинции: Автореф. дис. ... канд. геол.-мин. наук. М.: МГУ, 2002. 24 с.].

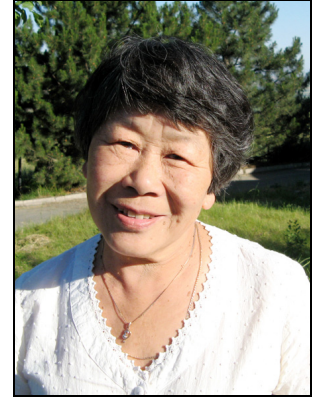

Сим Лидия Андреевна, докт. геол.-мин. наук, в.н.с.

Институт физики Земли им. О.Ю. Шмидта РАН

123995, Москва, ул. Большая Грузинская, 10, стр. 1, Россия

$\bowtie$ e-mail: sim@ifz.ru

Sim, Lidia A., Doctor of Geology and Mineralogy, Lead Researcher

The Schmidt Institute of Physics of the Earth RAS

10-1 Bolshaya Gruzinskaya street, Moscow 123995, Russia

\e-mail: sim@ifz.ru 